\title{
Reburial of Mosaics: Field Experiment Comparing Six Different Systems Based on the Results of Monitoring Station in Perge
}

\section{Mozaiklerin Tekrar Gömülmesi: Perge' de Kurulan İzleme İstasyonu Sonuçlarına Göre Altı Farklı Gömme Sisteminin Karşılaştırılması}

\author{
Şehrigül YEŞIL*
}

(Received 31 March 2021, accepted after revision 12 September 2021)

\begin{abstract}
The effectiveness of six different reburial systems was investigated by means of a monitoring station installed on a part of approximately 110 square meters of mosaic, defined as basilica thermarum in the Southern Baths of the ancient city of Perge. The scope of the study covers the monitoring of six different reburial systems consisting of only soil filling on the tessellatum layer; only sand filling on the tessellatum layer; sand filling on geotextile laid on the tessellatum surface; sand and gravel, respectively on geotextile laid on the tessellatum surface; geotextile and pozzolana on the tessellatum surface, and finally, approximately $5 \mathrm{~cm}$ sand, geotextile, and $15 \mathrm{~cm}$ sand on the tessellatum surface. Key parameters, which lead to deterioration such as moisture content in these systems, system response to the precipitation, temperature change, acidity, salt content, and plant formation were evaluated comparatively.

In these systems, Decagon 10HS soil moisture sensor for moisture measurements and Apogee ST100 soil temperature sensor for temperature measurements were employed. Atmospheric humidity, atmospheric temperature and precipitation data were collected with a Davis ${ }^{\circledR}$ Vantage Vue ${ }^{\mathrm{TM}}$ Wireless Weather Station set. Data of salt content, acidity and elemental composition were obtained through conductivity analysis, $p H$ tests, X-ray fluorescence (PED-XRF) analysis. Having reached under the reburial system, species analysis of plants that cause mosaic deterioration was realized, and the coverage degree of those plants was determined according to the Braun-Blanquet cover-abundance scale. This research, in which data for the years 20172018 were evaluated, showed that each monitored reburial system had certain advantages and disadvantages according to the above-mentioned parameters.
\end{abstract}

Keywords: Perge, reburial, mosaics, conservation, archaeometry, in situ conservation.

Öz

Perge antik kenti, Güney Hamam'daki basilica thermarum olarak tanımlanan mekân mozaiğinin yaklaşık 110 metrekarelik bir bölümü üzerinde kurulan bir izleme istasyonuyla altı farklı tekrar gömme sisteminin etkinliği araştırılmıştır. Araştırma kapsamında, 1. tessellatum tabakası üzerine sadece toprak dolgu malzemesi; 2. tessellatum tabakası üzerine sadece kum dolgu malzemesi; 3. tessellatum yüzeyine serilen jeotekstil üzerine kum dolgu malzemesi; 4. tessellatum yüzeyine serilen jeotekstil üzerine sirasiyla kum ve çakıl; 5. tessellatum yüzeyine jeotekstil ve pozzolana ve son olarak; 6. tessellatum yüzeyine sirasıyla, yaklaşı $5 \mathrm{~cm}$ kum, jeotekstil ve tekrar $15 \mathrm{~cm}$ kum ile oluşturulan tekrar gömme sistemleri incelenmiştir. Bu sistemlerdeki nem kapasitesi, sistemlerin yă̆ışlara verdiği tepki, sıcaklık değişimi, asidite, tuzluluk ve bitki oluşumu gibi bozulmaya yol açan anahtar parametreler karşılaştırmalı olarak değerlendirilmiştir.

Sistemlerdeki nem ölçümleri için Decagon 10HS toprak nem sensörü, sicaklık ölçümleri için Apogee ST100 toprak sıcaklık sensörü kullanılmıştır. Atmosferik nem, atmosferik sıcaklık ve yağıs verileri Davis ${ }^{\circledR}$ Vantage Vue ${ }^{\mathrm{TM}}$ Wireless Weather Station meteoroloji istasyonu seti ile toplanmıştır. Iletkenlik analizi, pH testleri, X-

\footnotetext{
SŞehrigül Yeşil, Işık University, Vocational School, Architectural Restoration Department, İstanbul, Türkiye. 5933. E-mail: sehrigul.yesil@isikun.edu.tr 
ışını floresan (PED-XRF) analizleri ile tuzlanma, asidite ve elemental kompozisyon verileri elde edilmiştir. Tekrar gömme sistemi altına ulaşarak mozaiklerin tahribine yolaçan bitkilerin cins ve tür analizleri yapılmış; bitkilerin örtme dereceleri Braun-Blanquet skalasına göre saptanmıştır. 2017-2018 yıllarına ait verilerin değerlendirildiği araştırma, izlenen her gömme sisteminin yukarıda belirtilen parametrelere göre belli avantaj ve dezavantajlar taşıdığını göstermiştir.

Anahtar Kelimeler: Perge, tekrar gömme, mozaik, konservasyon, arkeometri, in situ koruma.

\section{Introduction}

Mosaics are laid in architectural structures for insulation, for creating a flat surface, and for decoration. The conservation of ancient mosaic pavement together with the architectural structure on which they are laid has gained increasing importance, beginning from the middle of the $20^{\text {th }}$ century. This was especially true from the last decade of the century, when it had become a standard practice in conservation works, except for cases such as where there was failure to provide preservation and security in the field. The use of shelters or protective buildings is common in terms of in situ conservation. It has always been a controversial issue in terms of the impact from the placement of pillars and mechanical loads of the building on the site. Besides this, the large masses of such structures often conflict with the archaeological landscape. Construction and maintenance costs are high for these structures. Further their applicability to a limited number of mosaics in the field creates an ethical conflict around availability. Due to these restrictions, reburial is the most commonly used method, especially for mosaic pavements covering very large areas.

Reburial is the conservation of archaeological objects or architectural elements by covering them with different fill and separation materials against atmospheric, environmental, and mechanical damages, as well as vandalism and theft. The methods of reburial and the selection of materials thereof vary according to the conditions, such as climatic conditions, the display and presentation approach in the archaeological site, the decision-making process regarding budget and conservation, countries, archaeological sites, and even the unique conditions of the mosaic within the same archaeological site. It is common to use soil, sand, gravel, pozzolana, and clay pellets as fill material for the reburial of mosaics. Fill materials are used alone or in combination with separation materials. The most preferred separation materials are plastic sheets, tarpaulins, various types of fabric, geomembranes, and geotextiles. Especially after the 2000s, there seems to be an increase in the use of geotextiles. Separation materials are often laid directly on the mosaic surface or used between two or more layers of fill materials.

Reburial is a method that has been practiced almost from the beginning of archaeological excavations (Demas 2004: 137). The application of a rigorous methodology, such as that applied to other types of conservation treatments, is still rare in practice for reburial interventions, and this is largely due to the lack of data regarding which materials should be used for reburial and how they should be utilized (Burch - Agnew 2004: 347). Little is known about the process of conservation, especially in areas with high or low levels of oxygen exposed to a wetting-drying cycle (Agnew et al. 2004: 134). A review of the literature concerning the reburial of archaeological sites reveals that a significant proportion addresses the issue of mosaics (Roby 2004: 229; Demas 2012). However, the number of studies investigating the behavior of shallow reburial systems (Burch - Agnew 2004; Roby 2004; Stewart 2004), especially against ecological deteriorative factors, as used in mosaics, is extremely limited. The common argument of scientific studies in the field is that the subject needs 
to be examined experimentally. A new field experiment method has been developed for research in terms of water/moisture content, temperature, acidity, salt content, and plant formation, which are the key parameters that lead to the deterioration of mosaic pavements, taking into account local conditions and the lack of knowledge in the field. A monitoring station was established on a part of approximately 110 square meters of mosaic in an area defined as the basilica thermarum in the Southern Bath of the ancient city of Perge. The aim behind the station's creation is to contribute to the practical development of the conservation method by reburial. It supports this goal by identifying advantages and disadvantages of six different reburial systems in line with the parameters in question through the data obtained from this monitoring station.

\section{Deterioration Factors in the Reburial Environment}

Mosaic pavements may be subject to deterioration in a reburial environment, mainly due to environmental factors, static or dynamic mechanical loads, or excavation, inappropriate restoration interventions, and human-induced reasons. The environmental disruptive/ deterioration factors that this research focuses on are interrelated. Water/moisture alone can cause physical and chemical damage; it is also directly related to acidity and salinity and is an important factor in promoting biological growth that is active in the deterioration of archaeological objects (Caple 2004: 158). Similarly, as temperature change plays an active role in $\mathrm{pH}$ and Eh change (Caple 2004: 157) in the reburial environment, chemical reactions and biological growths are accelerated at high temperatures (Cronyn 1990: 23). Acidity can dissolve calcium carbonate in stones and mortars, and also other minerals in stones. In addition to deterioration due to the crystallization pressure, salinity also leads to degradation by crustation on the surface. Plants cause deterioration by mechanical pressure of the roots, from carbon dioxide released from the roots, increasing organic components, causing stains and color change. In addition, carbon dioxide released from the roots has the potential to change the acidity in the environment (Caneva et al. 1991: 87-112). Measures to be taken against the degradation factors described above and the development of a new reburial system according to the climatic conditions of the region may be possible by understanding the ambient conditions and behavior of reburial systems against these conditions.

\section{Selection of the Experimental Area and the Place Where the Monitoring Station Will Be Established}

Field tests were carried out at a monitoring station established on a section of approximately 110 square meters of mosaic in an area defined as basilica thermarum (Özdizbay 2012: 37-38) (so-called Claudios ${ }^{1}$ Piso Hall) (Room VII) in the Southern Bath of the ancient city of Perge, located in Aksu District of Antalya (Fig. 1).

In systematic excavations in Perge, mosaic pavements covering large areas (Colonnaded Street, Southern Bath, South Basilica, Macellum) were unearthed in the 1970s and 1980s (Iş̧klıkaya-Laubcher 2016: 170) and partially restored between 1977-1987. All of the mosaics were reburied and taken under protection. After 2003, approximately 3000 square meters of mosaic pavements in the ancient city of Perge in Macellum, the portico along the east of the Late Antique town square (also called portico of the South Basilica) and the Southern Bath

1 The use of the Latin name Claudius Piso as Klaudios Peison in Greek is also common in publications (Özdizbay 2012: 38). 


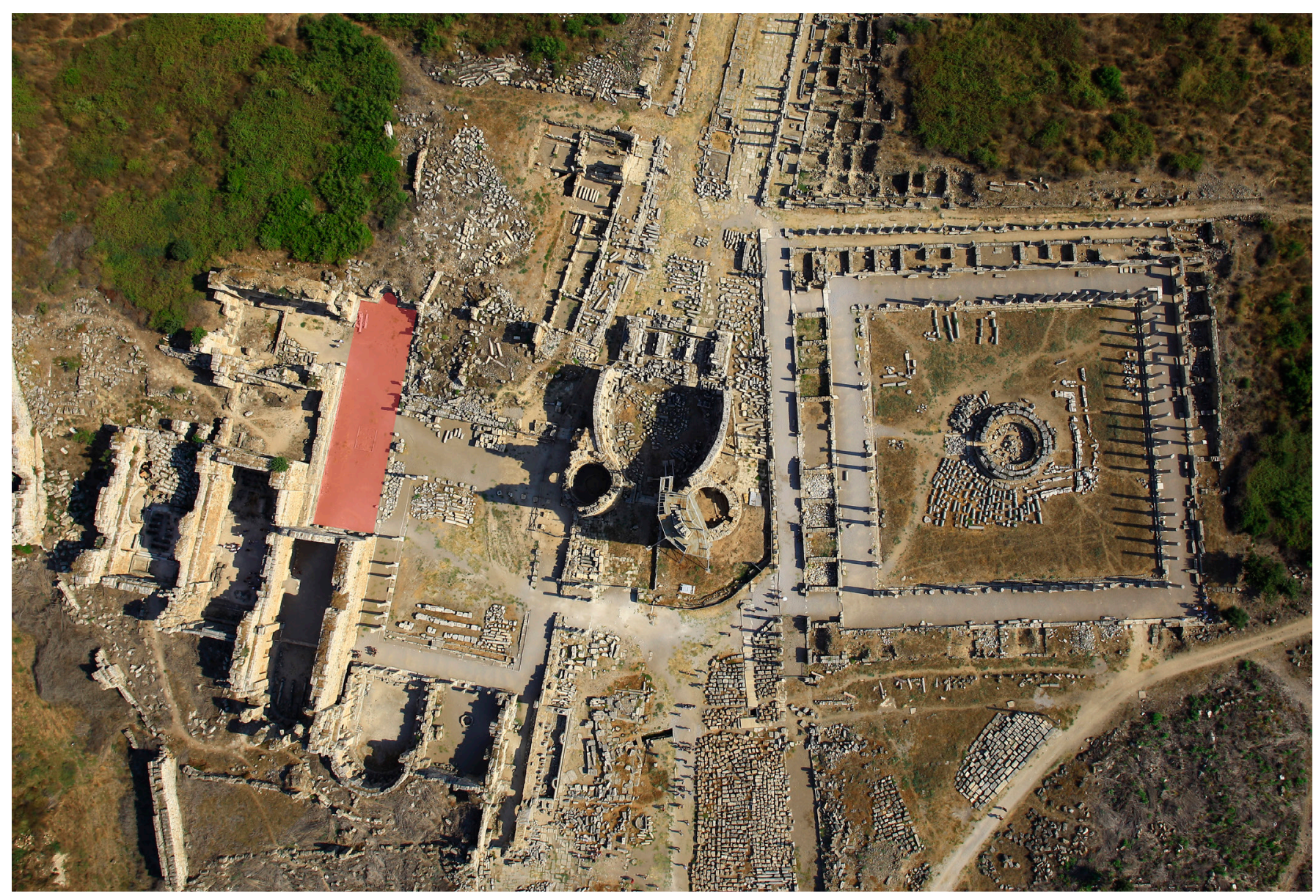

were examined comprehensively for the first time, and their documentation and archaeological research were carried out (Iş1klıkaya 2010). According to this research, pavements generally dated to the $4^{\text {th }}$ to $5^{\text {th }}$ centuries AD and attributed to 8 workshops (Işı1klıkaya-Laubscher 2016: 191-193).

There are two pavements that are large enough to set up the monitoring station and are attributed to the same workshop (Işsklıkaya-Laubscher 2016: 177). One of these is the Claudius Piso Gallery, and the other is the Northern Gallery of the Palaestra in the Southern Bath. According to characterization analysis, Claudius Piso Gallery mosaic mortars were examined in more detail in terms of density and porosity, which will have a greater effect on the moisture factor that is increasing by capillarity, and it was understood that the porosity of the samples taken was closer to each other (Uğur 2011: 112 table 21). Again, due to the destruction of the tessellatum layer (lacunae) and the original mortar on the same pavement, it was seen that, there was enough space for the test areas to be placed without damaging the mosaics (Erdek 2012: 111 cat no. 12). Unlike the pavement of the Northern gallery of the palaestra (Erdek 2012: 103 cat. no. 8/4), which was excavated in 1984, and restored according to the understanding of that period, and had a secondary restoration in 2006, the Claudius Piso Gallery was uncovered for the first time (Işıklıkaya 2010: 274 cat. no.14) and restored in 2017 (Erdek 2012: 119-120). Since we have more information about the restoration of the pavement of Claudius Piso Gallery and the materials used during the application (Erdek 2012: 111-114 cat. no. 12), it has led to the decision to continue the experiment in this area.
Figure 1

Ancient City of Perge, Southern Bath, Basilica Thermarum (Claudius Piso Gallery), Istanbul University, Perge Archive, 2011. 


\section{Selection of Reburial Systems Evaluated}

In terms of reburial, excavation reports published annually usually without interruptions, and presenting the work done during the excavation season are important for understanding the trend. Technical details are not included in the proceedings of "Kazı Sonuçları Toplantıları (KST, En: Excavation Results Meeting)", where the results of excavations and research projects carried out each year since the 1980s are presented. But despite this, in addition to KST, there are three other sources that are important in terms of reporting the reburial application; "Araştırma Sonuçları Toplantısı (AST, En: Research Results Meeting)", published since 1983; "Arkeometri Sonuçları Toplantısı (ArkST, En: Archaeometry Results Meeting)", published since 1985, and "Müze Çalışmaları ve Kurtarma Kazıları Sonuçları Sempozyumu (MKKS, En: Museum Studies and Rescue Excavations Results Symposium)". In the "Anadolu Akdenizi Arkeoloji Haberleri” (ANMED, News of Archaeology from Anatolia's Mediterranean Areas), which has been published since 2003 and where the excavations carried out in the Mediterranean Region, the reburial application has been reported briefly. In addition, the "Journal of Mosaic Research" is one of the periodicals that directly targets mosaic research and provides data on the topic ${ }^{2}$. A comprehensive literature review on the aforementioned periodicals and specific publications on mosaic conservation provides us with an idea of the methods used in reburial of in situ mosaics and the used/preferred separation/horizon marker materials and fill materials in Turkey. These publications also provide clues about the decision-making process for reburial, the criteria for selection of reburial systems, and the change of these preferences ${ }^{3}$. Reburial systems to be monitored in Perge have been selected according to the criteria that they are the most preferred/used methods in Turkey to date.

\section{Installation of Monitoring Station and Measuring Devices}

The experiment is based on a comparative investigation of six different reburial systems (systems 1-6) in terms of moisture, temperature, acidity, salinity and plant diversity, and density. In this experiment, systems using only fill material ${ }^{4}$ and systems in which fill materials and geotextile ${ }^{5}$ are used together as separators were tested.

Within the scope of the experiment, only soil as fill material on the tessellatum

2 A total of 83 volumes between the numbers 2. and 38-3 of KST, 62 volumes between the numbers 1. and 34. of AST, 38 volumes between the numbers 1. and 32. of ArkSt, all numbers between 1. and 26. of MKKS, all numbers printed between 1. and 13. of ANMED, and numbers 1. and 9. of JMR (1066 articles in total) were reviewed. Since the most frequently used reburial systems in Turkey were determined according to this screening in the experiment carried out in Perge, Southern Bath, basilica thermarum, where reburial systems were mutually evaluated, the study is limited to the numbers published until 2016

3 This comprehensive literature review will be published.

4 The fill materials used in the experiment are soil, sand, gravel, and pozzolana. The soil is excavated soil extracted from the archaeological site, obtained by sieving with a $2 \mathrm{~mm}$ sieve. Sand is $2 \mathrm{~mm}$ under-sieve stream sand, and gravel is stream gravel with $8-30 \mathrm{~mm}$ grain size. Pozzolana is a natural volcanic tuff with a grain size of $8-30 \mathrm{~mm}$. Sand, gravel, and pozzolana were obtained from the local service provider.

5 It has been determined by the above-mentioned literature research that geotextile is used as a separation material in the majority of reburial applications in Turkey, especially after the 2000s. Despite that, no technical features of geotextile are mentioned in any of the reports in the literature reviewed. For this reason, the selection of geotextiles to be used in the experiment was based on information obtained from the main manufacturers in the field and companies providing restoration materials to the excavation sites. Accordingly, $200 \mathrm{gr} / \mathrm{m}^{2}$ type of white geotextile produced by heat treatment method of non-woven, pure polypropylene-based fibers, which are stated to be most preferred by excavations, was chosen. 
layer (system 1), only soil as fill material on the tessellatum layer (system 2), sand as fill material on the geotextile laid on the tessellatum surface (system 3), sand and gravel on the geotextile laid on the tessellatum surface, respectively (system 4); geotextile and pozzolana (system 5) on the tessellatum surface pozzolana as fill material on the geotextile laid on the tessellatum surface (system 5) and, finally reburial systems on the tessellatum surface with approximately $5 \mathrm{~cm}$ of sand, geotextile and again $15 \mathrm{~cm}$ of sand (system 6) respectively, were investigated 6 . In order to collect statistical data, three sets representing the investigated six reburial systems were formed; the 1 st set was installed consecutively, the $2^{\text {nd }}$ and $3^{\text {rd }}$ sets were installed mixed-in their own set. In all field and laboratory analyses, the investigated systems are shown with "S" and the test areas with "A" (Fig. 2).
Figure 2

The Monitoring Station in the Claudius Piso Gallery, the Diagram Showing the Installation of Reburial Systems and Measuring Devices in the Test Areas. (Iş1klıkaya-Laubscher 2016: 208, Fig. 8. Drawn by Ş. Yeşil).

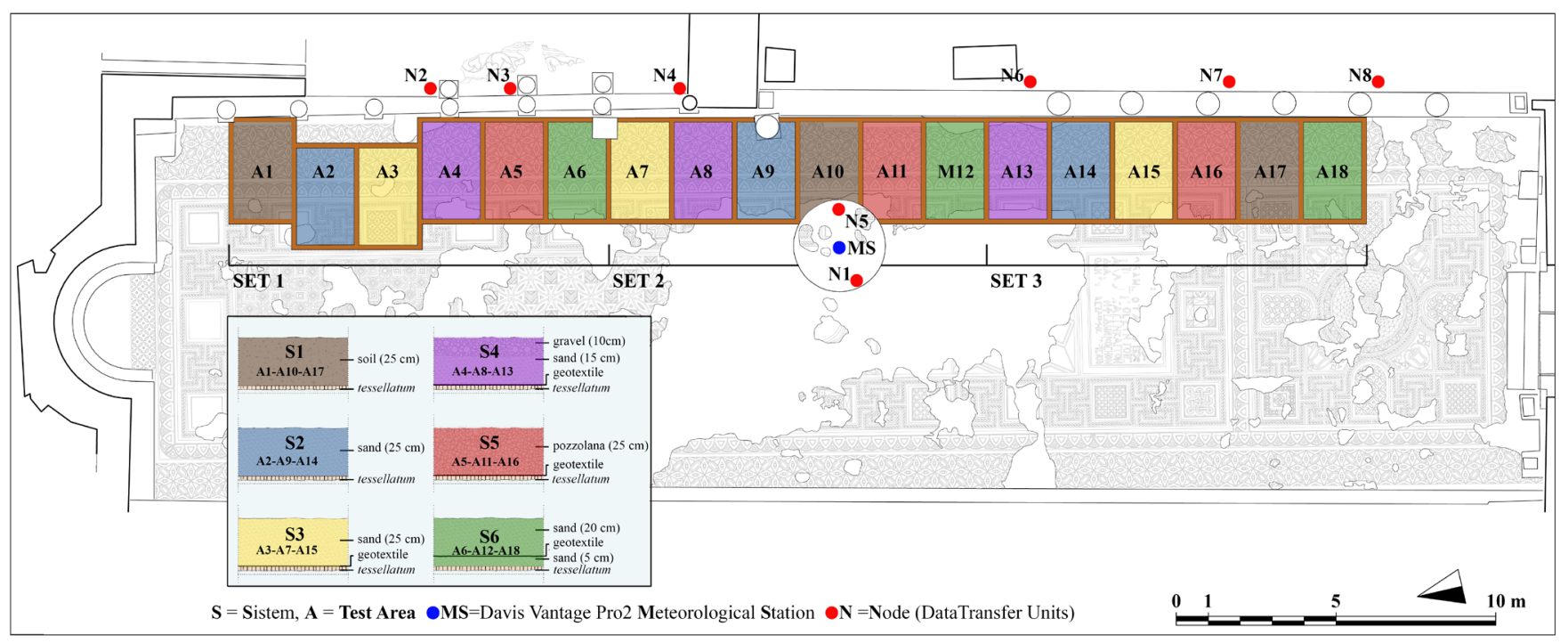

Accordingly, for system 1 (S1), data were obtained from test areas 1, 10, and 17 (A1, A10, A17), for system 2 (S2) from test areas 2, 9, and 14 (A2, A9, A14), for system 3 (S3) from test areas 3, 7, and 15 (A3, A7, A15), for system 4 (S4) from test areas 4, 8, and 13 (A4, A8, A13), for system 5 (S5) from test areas 5, 11 , and 16 (A5, A11, A16), for system 6 (S6) from test areas 6, 12, and 18 (A6, A12, A18) (Fig. 2).

In August 2015, test areas began to be placed. First of all, after restoration works carried out in August 2007, the reburial system which was only on part of the floor, where the test is to be placed, and consisting of geotextile and sand filling, was removed (Fig. 3a). The test areas are separated from each other by dry-walls approximately $25 \mathrm{~cm}$-high in situ location of unknown, which are formed by placing broken ancient brick pieces on top of each other (Fig. 3b). Accordingly, a monitoring station of about 110 square meters was created in total (Fig. 3c).

Ground moisture content was measured with Decagon 10HS soil moisture sensor at a depth of $60 \mathrm{~cm}$ from the points in the north and south of the experimental area, and approximately in the middle. Atmospheric temperature $\left({ }^{\circ} \mathrm{C}\right)$, relative humidity $(\%)$, precipitation amount $(\mathrm{mm})$ and precipitation rate $(\mathrm{mm} / \mathrm{h}$.) data

6 In the literature review, system 1 was reported 16 times; system 2, 19 times; system 3, 24 times; system 4, 7 times; and system 5, 12 times. System 6 was represented only once (Yeşil-Erdek 2014: 74-75) in publications in Turkey. However, in the case of laying geotextiles directly on the mosaic surface, it was found appropriate to be included in the experiment, taking into account the findings (Roby 2004: 234) that the geotextile adheres to the tesserae and increases the growth of capillary plant roots. 


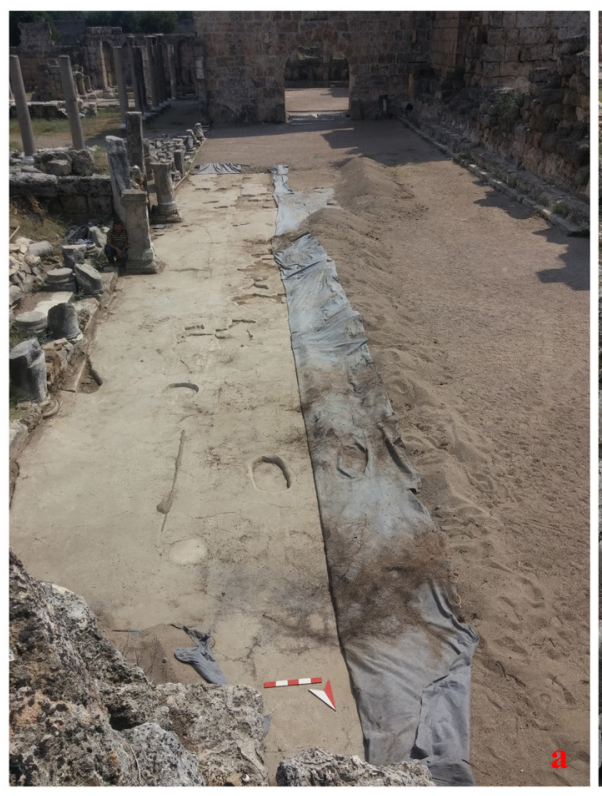

Figure 3

Installation of Monitoring Station, Test Areas and Measuring Devices.

Figure 4

Measurement and Data Transfer Devices and Layout Plan of a Test Area.
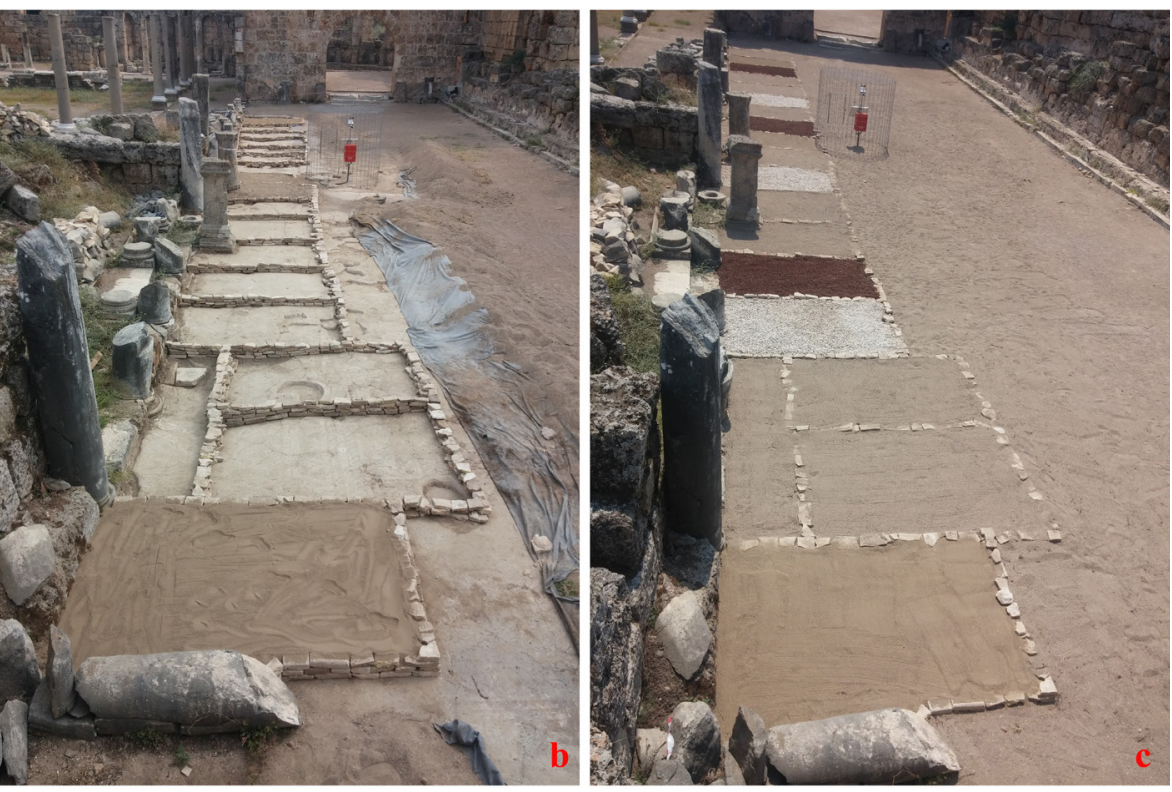

were obtained with the Davis ${ }^{\circledR}$ Vantage Vue ${ }^{\mathrm{TM}}$ Wireless Meteorology Station set (Fig. 4a). In reburial systems, moisture measurements were made with Decagon 10HS soil moisture sensor (Fig. 4b) and temperature measurements were conducted with an Apogee ST100 soil temperature sensor (Fig. 4c). The devices were installed approximately in the middle of each test area, at a point approximately $5 \mathrm{~cm}$ above the tessellatum, with an inclination of approximately 30 degrees. These are connected to the MiniSENSE wireless RF modem data transfer unit (Fig. 4d). When planning the size of the test areas, attention had been paid to them to ensure they were large enough to minimize the systems being affected by each other in terms of moisture content and temperature, and to ensure that the moisture and temperature sensors can be placed as far from each other as possible. Accordingly, each of the test areas is designed with a size of approximately $3 \times 2 \mathrm{~m}$ (Fig. 4e).

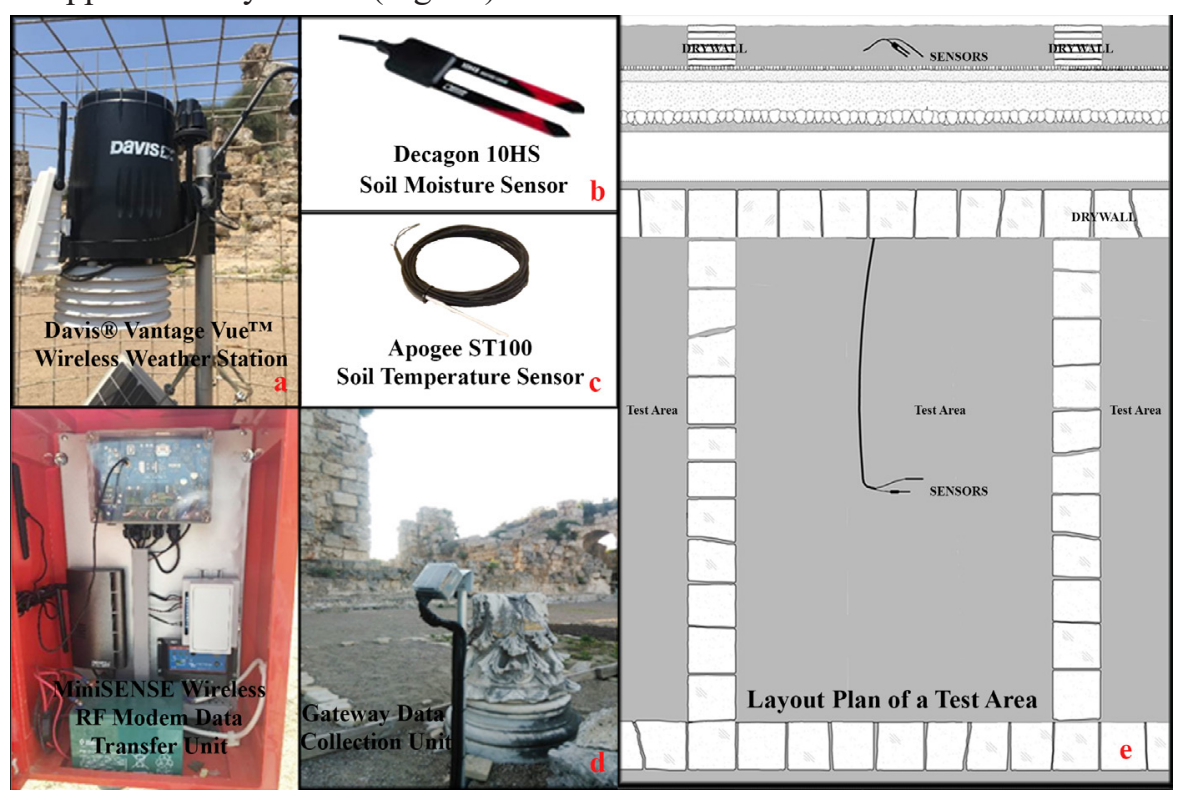

Since the devices and techniques used in different fields of science were tried for the first time to investigate shallow reburial systems used in pavements, the study started with testing the effectiveness of the devices in August 2015; then 
the malfunctions in data flow were resolved. Since July 2016, data transferred to the website of the service provider company could be tracked at 10 minute intervals.

\section{Evaluation of Findings}

Data for 2017-2018 were evaluated within the scope of the research. The average of the data taken from three separate test areas representing the same reburial system was used to evaluate their findings in the reburial systems. In the evaluation of the ground moisture content (\%) findings, the average of the moisture data taken from the north and south of the monitoring station and three points approximately in the middle of these (approximately $60 \mathrm{~cm}$ below the ground was used. Since it was determined that the highest temperature values of the day were reached at 16:00 in reburial systems, the four hours to be evaluated during the day were determined at six-hour intervals starting from 16:00 by dividing the 24 hours of the day into four. Data at 04:00, 10:00, 16:00 and 22:00 were evaluated for each day. In relation to this, data obtained at the same time of day were also used to evaluate temperature $\left({ }^{\circ} \mathrm{C}\right)$ and atmospheric relative humidity (\%) data obtained from the meteorological station. The evaluations were made over the annual minimum and maximum values and their average in order to see the difference in reburial systems, as well as atmospheric temperature $\left({ }^{\circ} \mathrm{C}\right)$ and atmospheric relative humidity (\%) between 2017 and 2018. In addition, monthly minimum values, monthly maximum values, and the average and standard deviation of daily data obtained during the month were determined in order to compare and evaluate the differences that occurred by months in the annual flow in 2017 and 2018.

The precipitation $(\mathrm{mm})$ and precipitation rate data $(\mathrm{mm} / \mathrm{h})$ taken from the meteorology station were recorded as days and hours of precipitation according to year. In addition, monthly and annual total precipitation, precipitation rate and number of rainy days were examined based on monthly values to provide a comparison by months during the year. In order to evaluate the daily change of data for two years, the annual flow was reflected with charts and the reburial systems were examined comparatively with these charts.

\section{Atmospheric Temperature $\left({ }^{\circ} \mathrm{C}\right)$ in the Monitoring Station}

When the atmospheric temperature values of 2017 and 2018 are examined (Table 1 ), it is understood that there is an increase of $1.2^{\circ} \mathrm{C}$ in 2018 . For both years, the month when the temperature values are the lowest is January, and the month when the temperature values are the highest is July. The highest temperature measured in the two-year test period is $44.4^{\circ} \mathrm{C}$ (July 2017, 16:00), the lowest temperature is $1.6^{\circ} \mathrm{C}$ (January 2017, 04:00).

When the temperature changes during the day are monitored over the annual and monthly averages, the lowest values of the day are taken at 04:00 and the highest values are observed at 10:00. The fastest increase is observed between these two hours, with some increase at 16:00 in the cold months, while a small decrease is observed during warm months. At 22:00 there is a significant difference in the direction of the decrease, and the values approach to data of 04:00. Based on data from both years, it can be stated that the temperature change during the day in the cold months is about $6^{\circ} \mathrm{C}$ and $10.5^{\circ} \mathrm{C}$ in the warm months. The temperature difference between the coldest and the warmest month in 2017 is about $22^{\circ} \mathrm{C}$, while it is $18.4^{\circ} \mathrm{C}$ in 2018 . Although there is a difference of approximately $3.5^{\circ} \mathrm{C}$ between these two years, it can be said that a temperature difference of approximately $20^{\circ} \mathrm{C}$ occurs between the hottest and the coldest months. 


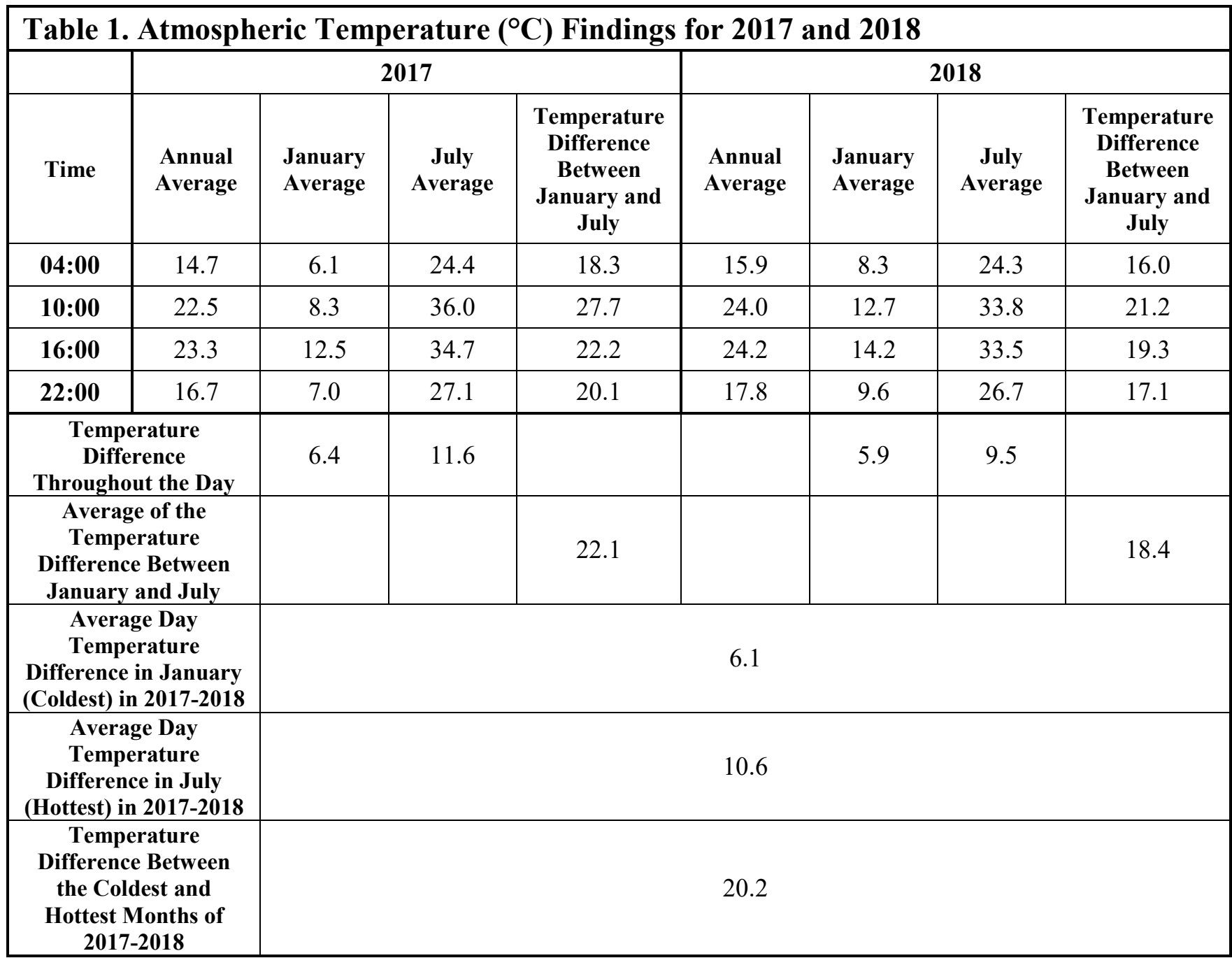

Table 1

Atmospheric Temperature $\left({ }^{\circ} \mathrm{C}\right)$ Findings for 2017 and 2018.
Since all temperatures are above $0^{\circ} \mathrm{C}$, there is no risk of freeze-thaw, which is one of the important deterioration factors in our experimental area.

\section{Atmospheric Relative Humidity (\%) in the Monitoring Station}

In 2017, the lowest relative humidity values were measured in July, and the highest values were measured in December. Data of 2018 presented quite different values when compared to 2017 data. As is known, the relative humidity of the air, the capacity of the air to absorb water vapor, evaporation rate, temperature, air pressure, wind etc. depend on many complex factors. Therefore, it is common for the relative humidity to differ according to these two years, during which data is collected as a part of the experiment, and the months of these years. On the other hand, since the data will directly depend on the temperature changes during the day, the change during the day offers clearer results. Differences up to $75 \%$ were read at the same time of day within a month. However, the examination of the averages shows that while the lowest relative humidity is observed at 10:00 and 16:00 during the day, the highest relative humidity values are consistently measured at 04:00 and 22:00 due to the decrease in the temperature.

Precipitation ( $\mathrm{mm}$ ) in the Monitoring Station

$511 \mathrm{~mm}$ of precipitation was observed in 69 rainy days in 2017, and the annual average precipitation is $46 \mathrm{~mm}$. In the 70 rainy days in $2018,786 \mathrm{~mm}$ 
of precipitation was observed, and the annual average precipitation is $66 \mathrm{~mm}$. Accordingly, although the number of rainy days per year is almost the same, the amount of precipitation increased significantly in 2018 (Table 2).
Table 2

Precipitation (mm) Findings for 2017 and 2018.

\begin{tabular}{|c|c|c|c|c|}
\hline Year & Month & $\begin{array}{c}\text { Number of Rainy } \\
\text { Days }\end{array}$ & Precipitation (mm) & $\begin{array}{c}\text { Precipitation Rate } \\
(\mathrm{mm} / \mathrm{h})\end{array}$ \\
\hline \multirow{14}{*}{2017} & January & 10 & 22 & 119.4 \\
\hline & February & 5 & 4 & 26.8 \\
\hline & March & 10 & 115 & 759.8 \\
\hline & April & 5 & 49 & 287.6 \\
\hline & May & 6 & 78 & 503.4 \\
\hline & June & 2 & 1 & 0.0 \\
\hline & July & 0 & 0 & 0.0 \\
\hline & August & 1 & $0 *$ & 0.0 \\
\hline & September & 1 & 1 & 4.8 \\
\hline & October & 6 & 47 & 314.8 \\
\hline & November & 11 & 74 & 512.6 \\
\hline & December & 12 & 119 & 763.0 \\
\hline & Annual Total & 69 & 511 & \\
\hline & Average & & 46 & 274.4 \\
\hline \multirow{14}{*}{2018} & January & 12 & 115 & 769.0 \\
\hline & February & 12 & 130 & 965.6 \\
\hline & March & 6 & 98 & 756.6 \\
\hline & April & 0 & 0 & 0.0 \\
\hline & May & 3 & 10 & 65.2 \\
\hline & June & 2 & 70 & 425.0 \\
\hline & July & 1 & 2 & 18.6 \\
\hline & August & 0 & 0 & 0.0 \\
\hline & September & 3 & 15 & 94.2 \\
\hline & October & 5 & 46 & 365.6 \\
\hline & November & 10 & 84 & 573.8 \\
\hline & December & 16 & 216 & 1411.6 \\
\hline & Annual Total & 70 & 786 & \\
\hline & Average & & 66 & 453.8 \\
\hline
\end{tabular}

* Precipitation observed but below $1 \mathrm{~mm}$.

Ground Moisture Content (\%) in the Monitoring Station

There is no significant change in the rate of ground moisture content (\%) during the hours in the day. The change in average annual values among the four hours evaluated during the day in 2017 (04:00, 10:00, 16:00, and 22:00), $\leq 0.3 \%$ while it is $\leq 0.6 \%$ in 2018 . Accordingly, it can be said that changes in the ground water rate during the day are quite slow (Table 3 ). 


\begin{tabular}{|c|c|c|c|c|c|c|c|c|}
\hline \multicolumn{9}{|c|}{ Table 3. Ground Moisture (\%) Findings for 2017 and 2018} \\
\hline & \multicolumn{4}{|c|}{\begin{tabular}{|l|l}
2017 &
\end{tabular}} & \multicolumn{4}{|c|}{2018} \\
\hline Time & $\begin{array}{c}\text { Annual } \\
\text { Average }\end{array}$ & $\begin{array}{l}\text { January } \\
\text { Average }\end{array}$ & $\begin{array}{c}\text { September } \\
\text { Average }\end{array}$ & \begin{tabular}{|c|} 
Ground \\
Moisture \\
Difference \\
between \\
January and \\
September
\end{tabular} & $\begin{array}{l}\text { Annual } \\
\text { Average }\end{array}$ & $\begin{array}{c}\text { July } \\
\text { Avera } \\
\text { ge }\end{array}$ & $\begin{array}{c}\text { Decem } \\
\text { ber } \\
\text { Averag } \\
\text { e }\end{array}$ & $\begin{array}{c}\text { Ground } \\
\text { Moisture } \\
\text { Difference } \\
\text { between } \\
\text { December } \\
\text { and July }\end{array}$ \\
\hline 04:00 & 21.9 & 28.0 & 17.0 & 6.1 & 20.3 & 15.0 & 26.9 & 11.9 \\
\hline 10:00 & 22.0 & 28.5 & 17.1 & 6.5 & 20.7 & 15.3 & 26.4 & 11.1 \\
\hline 16:00 & 21.7 & 28.1 & 16.7 & 6.4 & 20.1 & 14.4 & 26.1 & 11.7 \\
\hline 22:00 & 21.7 & 27.8 & 16.8 & 6.1 & 20.2 & 14.5 & 27.6 & 13.1 \\
\hline $\begin{array}{c}\text { Ground } \\
\text { moisture } \\
\text { difference } \\
\text { during the } \\
\text { day }\end{array}$ & 0.3 & 0.7 & 0.4 & & 0.6 & 0.9 & 1.5 & \\
\hline $\begin{array}{c}\text { Difference } \\
\text { between low } \\
\text { and high } \\
\text { months } \\
\end{array}$ & & & & 6.3 & & & & 12.0 \\
\hline
\end{tabular}

Table 3

Ground Moisture Content (\%) Findings for 2017 and 2018.
Table 4

Annual Average Moisture Content (\%) Findings in the Reburial Systems.
Evaluation of Moisture Content (\%) Findings in the Reburial Systems

Despite the ratio differences in the moisture content $(\%)$ and temperature $\left({ }^{\circ} \mathrm{C}\right)$ values in the reburial systems, it was observed that in 2017 and 2018, they acted jointly according to seasons, precipitation, and ground moisture content levels. A general evaluation can be made when the moisture rates of the systems are compared based on the 2017 and 2018 annual average moisture content findings (Table 4)

According to table values, the highest annual moisture content values in all burial systems in $\mathbf{2 0 1 7}$ were measured in the S1 reburial system (24.9 at 04:00, 25 at 10:00, 25.1 at 16:00 and 24.9 at 22:00) created with soil fill material. This system is followed by the S2 system (20.4 at 04:00 and 10:00, 20.3 at 16:00 and 22:00), which is formed by sand fill material. The values of the S6 system (20.2 at both 04:00 and 16:00, 20.4 at 10:00, and 20 at 22:00), created on the tessellatum layer first with sand, geotextile, and sand again, are very close to the S2 system, but somewhat lower. The values of the S4 reburial system (19.4 at 04:00, 19.5 at both 10:00 and 16:00 and 19.4 at 22:00) created by geotextile, sand, and gravel on the tessellatum layer provided slightly lower values than the $\mathrm{S} 1, \mathrm{~S} 2$ and S6 systems.
Table 4. Annual Average Moisture Content (\%) Findings in the Reburial Systems

\begin{tabular}{|c|c|c|c|c|c|c|c|c|}
\hline & \multicolumn{9}{|c|}{$\mathbf{2 0 1 7}$} & \multicolumn{4}{|c|}{$\mathbf{2 0 1 8}$} \\
\hline System & $\mathbf{0 4 : 0 0}$ & $\mathbf{1 0 : 0 0}$ & $\mathbf{1 6 : 0 0}$ & $\mathbf{2 2 : 0 0}$ & $\mathbf{0 4 : 0 0}$ & $\mathbf{1 0 : 0 0}$ & $\mathbf{1 6 : 0 0}$ & $\mathbf{2 2 : 0 0}$ \\
\hline S1 & 24.9 & 25.0 & 25.1 & 24.9 & 25.3 & 25.4 & 25.5 & 25.4 \\
\hline S2 & 20.4 & 20.4 & 20.3 & 20.3 & 15.1 & 15.1 & 14.9 & 15.1 \\
\hline S3 & 15.7 & 16.0 & 15.7 & 15.5 & 15.5 & 15.5 & 15.1 & 15.2 \\
\hline S4 & 19.4 & 19.5 & 19.5 & 19.4 & 19.6 & 19.7 & 19.6 & 19.7 \\
\hline S5 & 17.3 & 17.2 & 17.5 & 17.3 & 17.8 & 17.8 & 17.9 & 17.9 \\
\hline S6 & 20.2 & 20.4 & 20.2 & 20.0 & 21.6 & 21.9 & 21.6 & 21.5 \\
\hline
\end{tabular}


Slightly lower moisture content values compared to these systems are obtained from the S5 system (17.3 at 04:00, 17.2 at 10:00, 17.5 at 16:00 and 17.3 at 22:00) made with geotextile and pozzolana. In 2017, S3 reburial system made with geotextile and sand on the tessellatum layer gave the lowest humidity values among all systems (15.7 at both 04:00 and 16:00, 16 at 10:00 and 15.5 at 22:00). It can be said that there is a parallelism in annual average humidity values in $\mathbf{2 0 1 8}$ as well, although there seems to be a slight increase due to the increase in precipitation. The only exception is the S2 reburial system made with sand fill material. In 2017, when data was obtained from the experimental area, the S2 system showed the highest moisture content values after the S1 soil reburial system. In 2018 the humidity values of the S2 system showed a significant decrease (15.1 at 04:00, 10:00 and 22:00, and 14.9 at 16:00) and reached approximately same values (15.5 at both $04: 00$ and 10:00, 15.1 at 16:00, and 15.2 at 22:00) with the S3 system created with geotextile and sand, which gave the lowest moisture content. In these systems, where the fill material is sand, it was observed that geotextile provided a significant advantage in moisture transfer in 2017, while the values were almost equal in 2018, which indicates that the effectiveness of geotextile in systems using sand as fill material should be investigated in a long-term and comprehensive manner. However, in the S6 system, where sand fill material is used, but the geotextile is not laid directly on the tessellatum layer, rather used after the $5 \mathrm{~cm}$ sand layer, the moisture content is higher compared to the $\mathrm{S} 3$ system, where the geotextile is used directly on the mosaic surface and is very close to the $\mathrm{S} 2$ system. This finding indicates that the use of geotextile as a separator between two layers of the fill materials rather than on the surface of the tessellatum is not as effective as using it directly in contact with the mosaic. The fact that the moisture rate in the S4 system, which has a sand and a gravel layer on the geotextile laid directly on the tessellatum, is higher than in the S2 and S3 systems can be explained by the fact that due to the large porous structure of the upper gravel layer, it breaks the capillarity that allows the moisture content in the system to evaporate. In the S4 system, the top layer of gravel is thought to reduce the evaporation of the water contained in the reburial system, just as is expected from the process of reducing the loss of water in the deep layers by evaporation through breaking the capillarity in the soil with shallow soil cultivation (digging of the soil) after planting seedlings in afforestation processes (Boydak - Çalışkan 2014: 284).

In 2017, the highest moisture content values were observed in January (Table 5). In this month, the highest moisture content in the $\mathrm{S} 1$ system is about $35 \%$ every four hours. Approximately $29.1 \%$ moisture content was measured in the S2 system at four hours of the day, $24 \%$ in the S3 system, $24.6 \%$ in the S4 system, $24.5 \%$ in the S5 system and $28.6 \%$ in the S6 system. These values are parallel between reburial systems in terms of the highest and the lowest moisture rates. In 2018, the highest moisture content values were detected in the S1, S4, and S6 systems in January and in the S2, S3, and S5 systems in December. In January, the highest moisture content in the S1 system is about 33\% every four hours. Values of about $24 \%$ were obtained in the S4 system at four hours of the day and $28.5 \%$ in the $\mathrm{S} 6$ system. 


\begin{tabular}{|c|c|c|c|c|c|c|c|c|c|}
\hline \multicolumn{7}{|c|}{ Table 5. Monthly Moisture Content (\%) Findings in the Reburial Systems } \\
\hline \multicolumn{2}{|c|}{ Highest } & $\mathbf{2 0 1 7}$ & \multicolumn{2}{|c|}{$\mathbf{2 0 1 8}$} & \multicolumn{2}{|c|}{$\mathbf{2 0 1 7}$} & \multicolumn{3}{|c|}{$\mathbf{2 0 1 8}$} \\
\hline & Sowest \\
\hline System & January & January & December & July & August & September & May & $\begin{array}{c}\text { Jul } \\
\text { y }\end{array}$ & August \\
\hline S1 & 34.9 & 32.9 & & & 16.8 & & & & 18.9 \\
\hline S2 & 29.1 & & 24.3 & 15.0 & & & 10.2 & & \\
\hline S3 & 24.0 & & 26.1 & & 10.1 & & & & 11.8 \\
\hline S4 & 24.6 & 24.2 & & 14.5 & 14.5 & & & & 14.8 \\
\hline S5 & 24.5 & & 27.8 & & & 10.4 & & & 11.9 \\
\hline S6 & 28.6 & 28.5 & & 13.6 & & & & 14.6 & \\
\hline
\end{tabular}

Table 5

Monthly Moisture Content (\%) Findings in the Reburial Systems.

Figure 5

Graph showing the moisture content (\%) and precipitation $(\mathrm{mm})$ data obtained from the Reburial Systems at 04:00 on 25 August-28 September 2016, 30 October-19 November 2016, and 6-24 September 2018
Moisture content was measured at the rate of $24.3 \%$ in S2 system, $26.1 \%$ in S3 system, and $27.8 \%$ in S5 system. These values show that the highest moisture content is again measured in the S1 system. This is followed by the S6 system, similar to annual rates. The most important factor determining the effectiveness of a reburial system is its lack of sudden response to precipitation (Roby 2004: 234). In other words, changing the moisture content balance as slowly as possible is one of the important features expected from a reburial system. The response of the reburial systems to the first precipitation following a dry period can be monitored with graphs, in which moisture content changes in six systems tested over four hours of data during the day can be monitored collectively ${ }^{7}$. Here, the data obtained at 04:00 on 25 August-28 September 2016 (Fig. 5a), 30 October-19 November 2016 (Fig. 5b) and 6-24 September 2018 (Fig. 5c) are shown as an example.

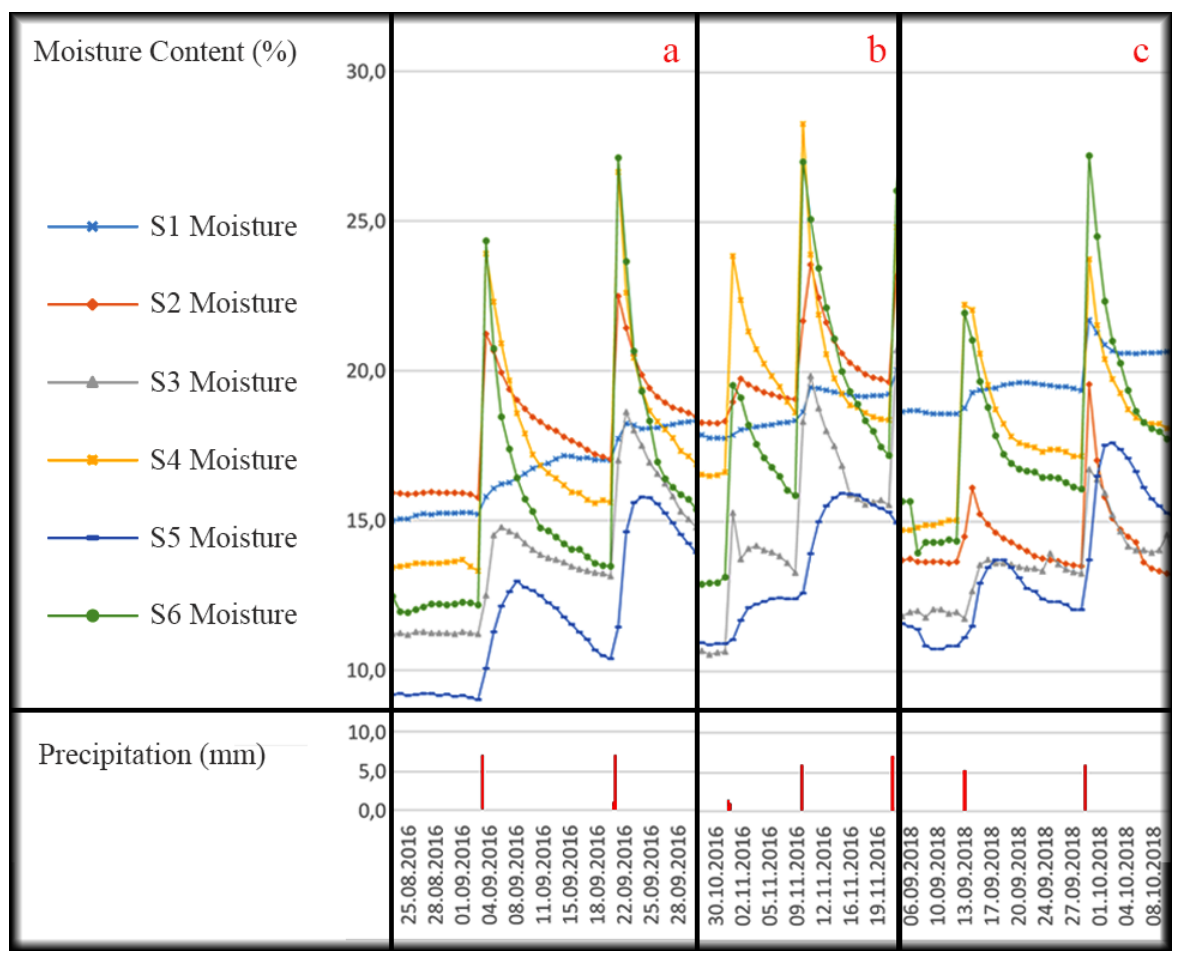

7 The charts where the moisture content changes, atmospheric temperature, atmospheric humidity, ground moisture content, and precipitation data can be monitored collectively in the six systems tested on daily four-hour data from July 2016 to the end of December 2018 are too large to be published here. For this reason, sample date ranges are shown here where changes can be clearly seen. For detailed information, Erdek 2019: Ek. 3 Lev. 1-12 
Accordingly, it can be observed that the S5 reburial system created by geotextile and pozzolana filling reacts more slowly to the first precipitation after a dry period than other systems. In this regard, it can be said that the S3 system is also somewhat more advantageous than other reburial systems. From this point of view, the S4 system created with geotextile, sand, and gravel, the S6 system created with $5 \mathrm{~cm}$ sand, geotextile, and sand again on the tessellatum layer and $\mathrm{S} 2$ systems created using only sand fill react more rapidly to precipitation than other systems and are disadvantageous in this respect.

\section{Evaluation of Temperature $\left({ }^{\circ} \mathrm{C}\right)$ Findings in the Reburial Systems}

The temperature findings in the 2017 and 2018 reburial systems show that the systems act jointly according to seasons, precipitation, and ground moisture content levels. The annual average temperature findings of 2017 and 2018, according to the four hours of the day, are reflected in Table 6. A general assessment can be made when the temperature ratios of the systems are compared over the annual findings.

\begin{tabular}{|c|c|c|c|c|c|c|c|c|}
\hline \multicolumn{9}{|c|}{ Table 6. Annual Temperature $\left({ }^{\circ} \mathbf{C}\right)$ Findings in the Reburial Systems } \\
\hline & \multicolumn{9}{|c|}{$\mathbf{2 0 1 7}$} & \multicolumn{5}{|c|}{$\mathbf{2 0 1 8}$} \\
\hline System & $\mathbf{0 4 : 0 0}$ & $\mathbf{1 0 : 0 0}$ & $\mathbf{1 6 : 0 0}$ & $\mathbf{2 2 : 0 0}$ & $\mathbf{0 4 : 0 0}$ & $\mathbf{1 0 : 0 0}$ & $\mathbf{1 6 : 0 0}$ & $\mathbf{2 2 : 0 0}$ \\
\hline S1 & 20.6 & 19.8 & 23.3 & 22.4 & 22.2 & 21.0 & 24.4 & 23.5 \\
\hline S2 & 20.4 & 20.5 & 25.4 & 22.8 & 21.5 & 21.4 & 26.0 & 23.6 \\
\hline S3 & 19.6 & 22.6 & 26.4 & 22.2 & 22.4 & 22.9 & 28.1 & 25.0 \\
\hline S4 & 19.0 & 18.9 & 23.4 & 21.1 & 20.2 & 20.2 & 24.4 & 22.2 \\
\hline S5 & 19.6 & 19.2 & 22.0 & 21.1 & 20.9 & 20.7 & 23.5 & 22.1 \\
\hline S6 & 18.5 & 22.6 & 27.0 & 21.2 & 20.5 & 24.0 & 28.9 & 23.1 \\
\hline
\end{tabular}

According to values of Table 6, in 2017 and 2018, the highest temperature values $\left(27^{\circ} \mathrm{C}\right.$ at $16: 00$ in $2017,28.9^{\circ} \mathrm{C}$ at $16: 00$ in 2018$)$ were measured in the S6 reburial system, which was created on the tessellatum layer first with sand, then geotextile, and again with sand. The lowest values were observed in the $\mathrm{S} 4$ system $\left(18.9^{\circ} \mathrm{C}\right.$ in 2017 at 10:00) created by geotextile, sand, and gravel on the tessellatum layer and in the S5 reburial system $\left(20.2^{\circ} \mathrm{C}\right.$ in 2018 at $04: 00$ and 10:00) created by geotextile and pozzolana. In all reburial systems, measured values from reburial systems vary in relation to atmospheric temperature data.

Examination of the difference between the annual averages of the highest and the lowest values obtained from the reburial systems during the day provides an idea of the reburial system that least reflects the atmospheric temperature differences to the mosaic pavement. According to values of Table 7, when examining the annual average of four hours of daily data in 2017 and 2018, it can be observed that the temperature change during the day is the highest (8.4 in 2017 and 8.5 in 2018 ) in the S6 reburial system created on the tessellatum layer first with sand, then geotextile, and again with sand. The difference in change in the S4 system, which is created with geotextile, sand, and gravel on the tessellatum layer, is about half of the S6 system, but at the same time is high (4.4 in 2017 and 4.2 in 2018). These systems are followed by the S1 system, which is created with soil fill material. In 2017, the temperature difference during the day was lower (2.3 in S2 and 3.1 in S3) in the S2 system created only with sand, and the S3 system created with geotextile and sand. The two-fold increase of these values in 2018 (4.6 in S2 and 5.6 in S3) should be due to the decrease in the thickness of the fill layers of these systems over time. It was determined by observation that the decrease in the thickness of the fill layer in the test areas, representing the systems in question, was caused by the mechanical effect of precipitation
Table 6

Annual Temperature $\left({ }^{\circ} \mathrm{C}\right)$ Findings in the Reburial Systems. 
Table 7

Temperature Differences During the Day According to Annual Averages.

Figure 6

Graph showing atmospheric temperature $\left({ }^{\circ} \mathrm{C}\right)$ and the temperature data obtained from the reburial systems at 04:00, 10:00, 16:00 and 22:00 between 25 May and 19 September 2017.

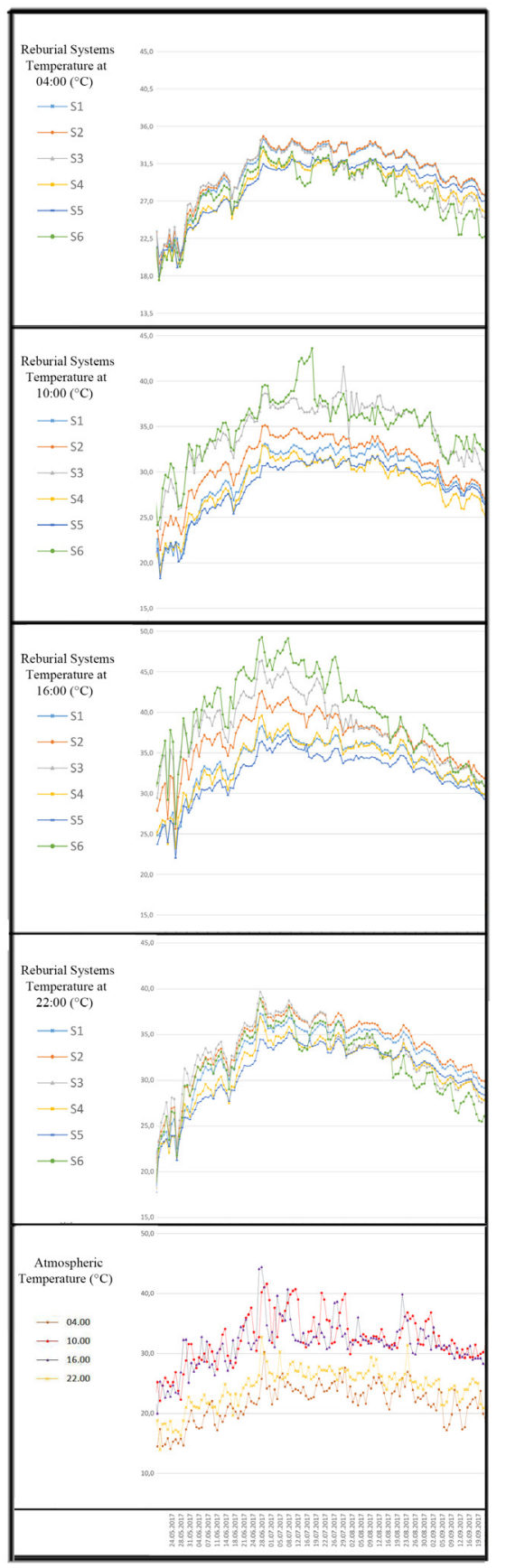

that made the sand fill with fluid or was caused by people and animals walking on the experimental area ${ }^{8}$.

\begin{tabular}{|c|c|c|}
\hline \multicolumn{3}{|c|}{ Table 7. Temperature Differences During the Day According to Annual Averages } \\
\hline System & $\mathbf{2 0 1 7}$ & $\mathbf{2 0 1 8}$ \\
\hline S1 & 3.4 & 3.4 \\
\hline S2 & 2.3 & 4.6 \\
\hline S3 & 3.1 & 5.6 \\
\hline S4 & 4.4 & 4.2 \\
\hline S5 & 2.8 & 2.8 \\
\hline S6 & 8.4 & 8.5 \\
\hline
\end{tabular}

The reburial system that least reflects the temperature differences during the day is the S5 reburial system, made with geotextile and pozzolana on the tessellatum layer. According to these findings, among the six reburial systems considered in the experiment, it can be said that the S5 system using pozzolana fill is the reburial system that least reflects temperature differences during the day to the pavement. This is followed by the S1 reburial system, which is created with soil fill material.

When the graphs showing daily temperature data from July 2016 to the end of December 2018 are examined over four hours a day ${ }^{9}$, it is possible to compare the systems to each other. The data obtained at four hours of the day between the dates of 25 May and 19 September 2017 are provided as an example here.

When the temperature data at 04:00 (Fig. 6a) and at 22:00 (Fig. 6d) are examined, it shows the lowest temperature values in the S6 system; it can be observed that it shows the highest values depending on the increase in atmospheric temperature at 10:00 (Fig. 6b) and 16:00 (Fig. 6c). Accordingly, it is understood that the system that gives the most sudden response to atmospheric temperature changes is the S6 system and it can be said that it is disadvantageous in maintaining a temperature balance.

Although it varies less than the $\mathbf{S 6}$ system, the $\mathbf{S 3}$ system is also sensitive to daily temperature changes. It is understood that the $\mathbf{S 5}$ reburial system made with pozzolana on the tessellatum layer reacts more slowly to temperature than other systems. It can be said that the reaction of the $\mathbf{S} \mathbf{1}$ system created by soil fill to temperature is also more balanced than other systems.

\section{Evaluation of Vegetation in the Reburial Systems}

The determination of the families, genus and species of plants found in the area and which led to the destruction of the mosaics by reaching under the temporary reburial system, and the measures to be taken against these were investigated. The first stage of the study is to collect plant samples in the area systematically and to record them on the vegetation sampling table (Kavgac1 2007: 28).

8 In the three test areas representing S2 and S3 systems, the thickness has decreased at different rates and although a common dimension has not been provided, it has been determined that the fill, which was initially made as $25 \mathrm{~cm}$, thinned up to $18 \mathrm{~cm}$ in places.

9 The charts where the temperature changes, atmospheric temperature, atmospheric relative humidity, ground moisture content and precipitation data can be monitored collectively in the six systems tested on daily four-hour data from July 2016 to the end of December 2018 are too large to be published here. For this reason, sample date range is shown here where changes can be clearly seen. For detailed information, Erdek 2019: Ek. 3 Lev. 1-12. 
Table 8a. Plant Species in the Test Areas, Their Number, and the Rate of Covering the Test Areas with Plants According to the Braun-Blanquet CoverAbundance Scale

\begin{tabular}{|c|l|l|l|c|}
\hline System & \multicolumn{1}{|c|}{ Set 1 } & \multicolumn{1}{|c|}{ Set 2 } & \multicolumn{1}{|c|}{ Set 3 } & $\begin{array}{c}\text { Average degree } \\
\text { of covering }\end{array}$ \\
\hline S1 & A1 (5=75-100\%) & A10 (5=75-100\%) & A17 (3=25-50\%) & 4.3 \\
\hline S2 & A2 (2=5-25\%) & A9 (1=<5\%) & A14 (1=<5\%) & 1.3 \\
\hline S3 & A3 (2=5-25\%) & A7 (2=5-25\%) & A15 (1=<5\%) & 1.7 \\
\hline S4 & A4 (3=\% 25-50) & A8 (2=\%5-25) & A13 (2=\% 5-25) & 2.3 \\
\hline S5 & A5 (3=\% 25-50) & A11 (1=<\%5) & A16 (1=<\%5) & 1.7 \\
\hline S6 & A6 (3=\% 25-50) & A12 (1=<\%5) & A18 (1=<\%5) & 1.7 \\
\hline
\end{tabular}

Table 8b. Number of Taxa in the Test Areas

\begin{tabular}{|c|l|l|l|c|c|}
\hline System & Set 1 & Set 2 & Set 3 & $\begin{array}{c}\text { Total number of } \\
\text { taxa }\end{array}$ & $\begin{array}{c}\text { Average } \\
\text { number of taxa }\end{array}$ \\
\hline S1 & A1 (9) & A10 (12) & A17 (8) & 28 & 9.3 \\
\hline S2 & A2 (6) & A9 (6) & A14 (5) & 17 & 5.7 \\
\hline S3 & A3 (6) & A7 (9) & A15 (7) & 22 & 7.3 \\
\hline S4 & A4 (7) & A8 (6) & A13 (12) & 25 & 8.3 \\
\hline S5 & A5 (4) & A11 (8) & A16 (4) & 16 & 6.3 \\
\hline S6 & A6 (11) & A12 (6) & A18 (2) & 19 & 6.3 \\
\hline
\end{tabular}

S: System, A: Test Area

Species diagnoses obtained were examined by being transferred to TURBOVEG software, species analyses were made ${ }^{10}$; and the degree of covering ${ }^{11}$ of plants was determined according to the Braun-Blanquet cover-abundance scale (BraunBlanquet 1928; 1932; 1964).

Among the six reburial systems tried, the highest degree of vegetation and number of species (Table $8 \mathrm{a}-\mathrm{b}$ ) were seen in the S1 system created by soil fill. High plant growth is expected in the S1 system because the soil is rich in organic matter. In addition, the fact that this system has the highest moisture content compared to all other systems is also one of the factors that increase plant development. Although the degree of vegetation covering in geotextile, sand, and gravel reburial system S4 is almost half that of the S1 system, it is quite high compared to the other systems. Since the moisture content is one of the top priority factors that will restrict the vegetation in the experimental area in the Mediterranean climate, excess moisture content in the S4 system (according to S3 and S5 in 2017, and according to S2, S3, and S5 systems in 2018) can have an effect on increasing vegetation rate. According to the degree of vegetation, S1 and $\mathrm{S} 4$ systems seem to be disadvantaged compared to other reburial systems. In S3, S5, and S6 systems, the common feature of which is a geotextile and a

10 Genus-species analysis of plants collected from the field was carried out by Assoc. Prof. Dr. Ali Kavgacı at the Batı Akdeniz Ormancılık Araştırma Enstitüsü (En: Western Mediterranean Forestry Research Institute). In vegetation studies, the main source was "Flora of Turkey and the East Aegean Islands" (Davis 1965-1985; Davis et al. 1988; Güner et al. 2000) and Tubives: Turkish Plants Data Service (Bakış et. al. 2011), which is an online data bank prepared for plants in Turkey, was used.

11 The degree of covering is the ratio of the vertical projections of the above-ground organs of the plants to the sample area (Aksoy 1978: 36). Since it is impossible to measure the above-ground parts of each plant species separately, the degree of covering is determined based on estimates (Kavgac1 2007: 29).
Table 8a

Plant Species in the Test Areas, Their Number, and the Rate of Covering the Test Areas with Plants According to the BraunBlanquet Cover-Abundance Scale.

Table 8b

Number of Taxa in the Test Areas. 
single fill material, the total covering degrees are very close to each other, and are considerably lower than the S4 system. Since the lowest result in terms of vegetation covering is obtained in the $\mathrm{S} 2$ system where the mosaic pavement is only buried with sand, it can be said that it is more advantageous compared to the others in this respect. In test areas buried with sand (S2) and pozzolana filling (S5), both the degree of covering is low, and the number of taxa is less. In this respect, it can be said that they are more suitable choices in terms of protecting mosaics from deterioration caused by plants. The degree of covering and the number of taxa are higher in the S3 reburial system made with geotextile and sand on the tessellatum surface than the $\mathrm{S} 2$ reburial system made with sand. This finding supports the observations in the literature that geotextile promote lateral root growth (Roby 2004: 234). In terms of preventing the destructive effects of plants, it is understood that the S2 reburial system, made with only sand, is more suitable under Perge conditions. In the S3 system, which is buried with geotextile as the first layer on tessellatum and sand on the mosaic pavement, and in the $\mathrm{S} 6$ burial system, which is made with $5 \mathrm{~cm}$ sand, geotextile, and sand respectively on the tessellatum surface, a higher number of plants are seen than reburial (S2) which is made only with sand. However, the number of species in the S6 system is less than in the S3 system. In light of this finding, it is thought that the use of geotextile as a separation after a thin layer of fill, rather than as the first layer on the mosaic pavement, may have an effect on the decrease of the number of species. This has led to the need for a longer-term comparison between the two systems.

Of the 39 plants identified in the Perge monitoring station, 37 are herbaceous plants and 2 are shrubs. The capers (capparis ovata sp.) in the study test areas are one of the plants with the most potential to cause damage with its deep taproot. Dog's tooth grass (cynodon dactylon) shows a wide and rapid spread both on the soil surface and on the fill and within the fill with its rhizomes as roots. The root length exceeds $1.50 \mathrm{~m}$, and the root thickness exceeds $2 \mathrm{~cm}$. capillary or main roots of species such as cynodon dactylon that manage to pass through the geotextile can directly reach the tessellatum in S2, S3, S4, and S5 systems, where geotextile is laid directly on the mosaic pavement. In these samples, it has been observed that the roots sometimes move into the mosaic pavement, but mostly run parallel to the surface between the tessellatum and the geotextile. In the S6 system, where first a thin layer of sand and geotextile and again sand fill was applied on the tessellatum, it was observed that the roots passed through the geotextile but moved in a horizontal direction parallel to the geotextile. Accordingly, it takes longer for the root to reach the tessellatum surface. In this regard, the S6 system seems to be more advantageous than the other systems with geotextile.

\section{Evaluation of Archaeometric Findings}

Archaeometric analyses within the scope of the research focused on the evaluations of salinity and acidity. For this purpose, fill materials used in the reburial systems were examined by conductometric analysis to determine the soluble salt content $(\% \mathrm{w} / \mathrm{w}), \mathrm{X}$-ray fluorescence (PED-XRF) analyses to determine the element contents $(\%)$ and $\mathrm{pH}$ tests. While the investigated systems are indicated with "S", and the test areas with "A", archaeometric analysis samples taken from the fill materials are coded by specifying the type of fill material (Fig. 7). Samples taken from test areas representing the S1 system created with soil fill material are coded as A1so, A10so and A17so. Samples taken from test areas representing the S2 system created with sand fill material are coded as A2s, 
A9s, A14s. Samples taken from the test areas representing the S3 system with geotextile on the tessellatum layer and sand as fill material are coded as A3s, A7s and A15s. In the S4 system, which has two fill layers consisting of sand and then gravel on the geotextile placed on the tessellatum layer, two samples are taken from the lowest point of both fill layers. Samples taken from the sand layer of the test areas representing the S4 system are coded as A4s, A8s and A13s; samples taken from the gravel layer are coded as A4g, A8g and A13g. Samples taken from the test areas representing the S5 system having geotextile on the tessellatum layer and pozzolana as fill material, are coded as A5p, A11p, and A16p. In the test areas representing the S6 system, where the geotextile is placed on the sand layer pre-laid, rather than the tessellatum layer, samples are taken from two layers. Samples taken from the lowest point of the $5 \mathrm{~cm}$ sand layer on the tessellatum are coded as A6s1, A12s1 and A18s1; samples taken from the geotextile layer were coded as A6s2, A12s2 and A18s2.
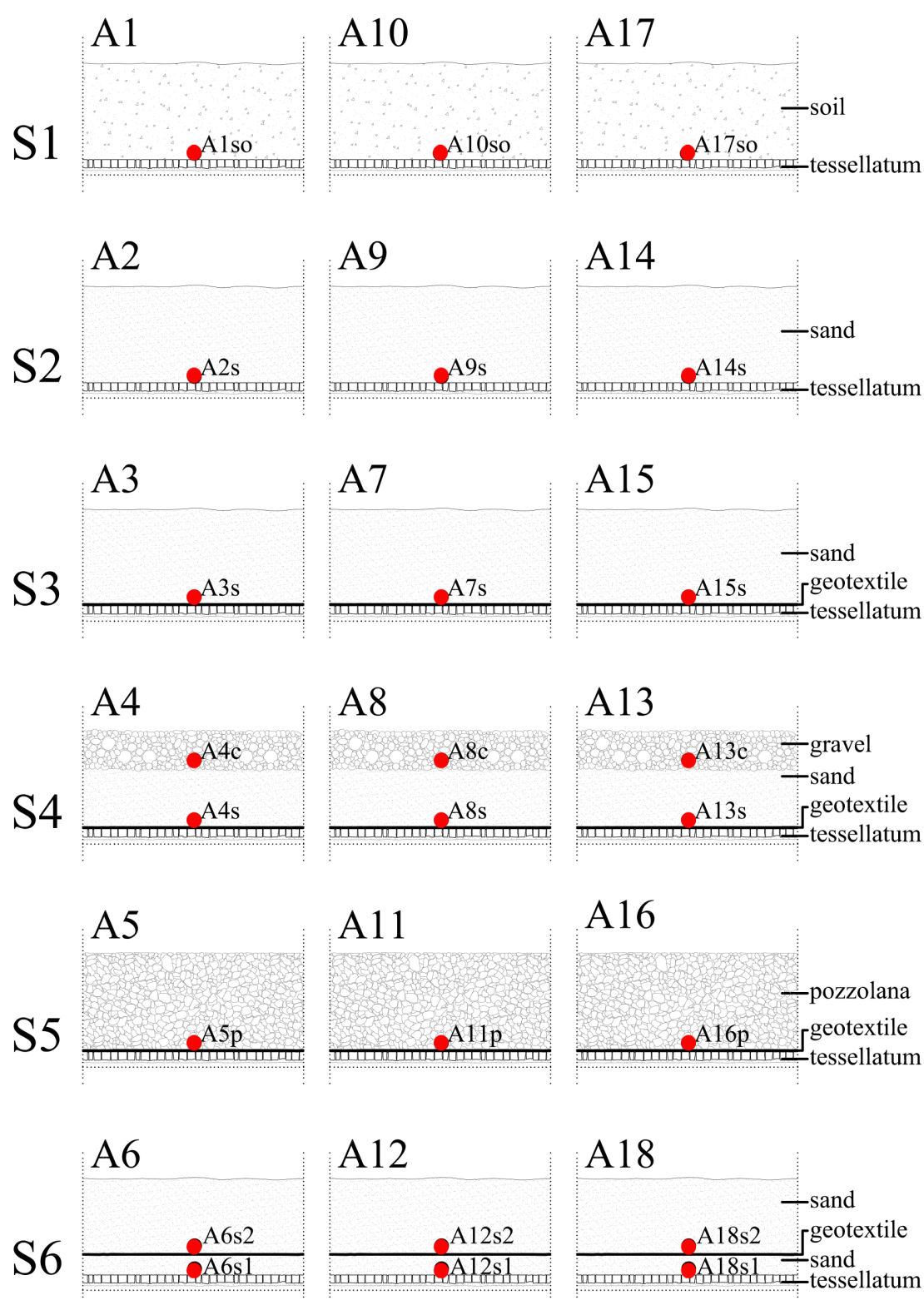

Figure 7

Explanations of Archaeometric Analysis Samples and Sample Points. 
Figure 8

Findings of $\mathrm{pH}$ Analysis of Fill Material Samples Taken from Test Areas.
Sand, gravel, and pozzolana (supplied by purchase) and soil (sifted excavated soil) were tested with the above-mentioned methods before being placed in the test areas (reference samples, August 2015). Subsequently, samples taken from the fills in the systems in July and December 2018 were tested and analyzed comparatively. It is impossible to make a comparison between fill materials obtained from different sources. The measurements made in July 2018 and December 2018 were compared before the materials were placed (reference samples, August 2015) in the test areas and after three years of use as fill material. The average of the data taken from three test areas representing the same reburial system was used to evaluate their findings in reburial systems in order to reach statistical data.

\section{Evaluation of $\mathrm{pH}$ Findings}

The highest $\mathrm{pH}$ value was measured in soil samples (8.21) in the reference samples. The $\mathrm{pH}$ values measured in pozzolana samples (8.10) are slightly lower than the soil samples. The lowest $\mathrm{pH}$ values were measured in sand (8.06) and in gravel (8.01) samples. The greatest difference between $\mathrm{pH}$ levels was gravel (8.01), which has the lowest $\mathrm{pH}$ values in reference samples, and soil, where the highest value was 0.20 . However the values got closer to each other and the difference decreased to 0.11 in July 2018. In all systems except the S1 system created with soil (8.18), $\mathrm{pH}$ values increased in July 2018 measurements. In December 2018, values got closer to each other; the difference decreased to 0.06 .

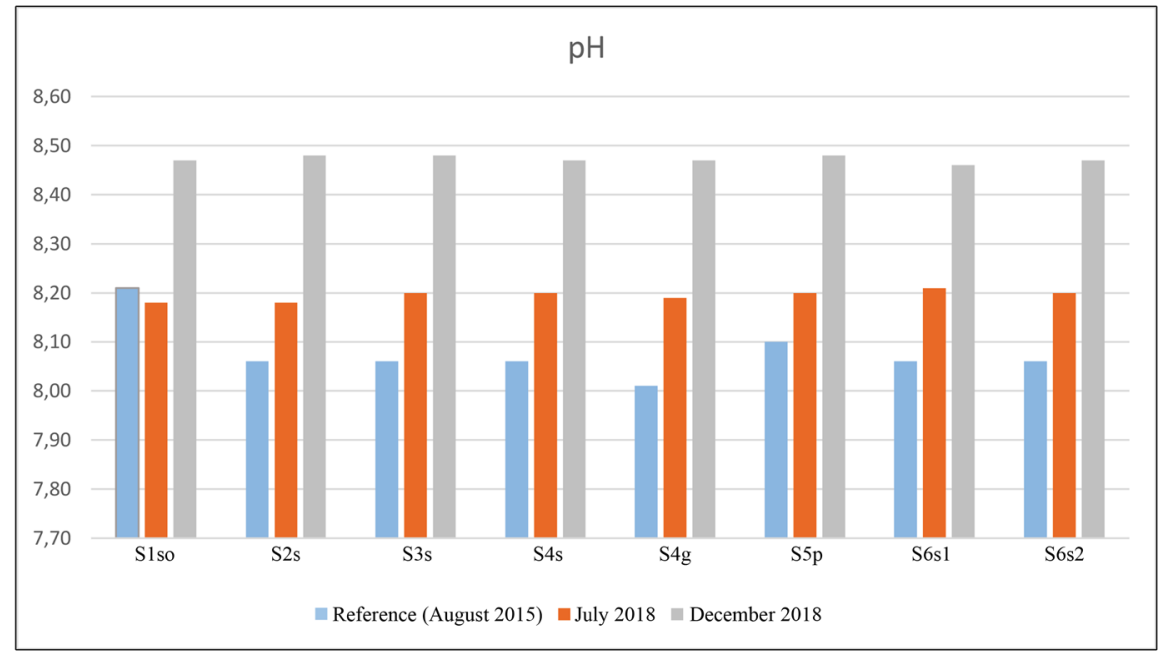

Coding: $\mathbf{S}=$ System (1-6); $\mathbf{A}=$ Test Area (1-18); so: soil, s: sand, g: gravel, p: pozzolana. Reference: Values taken before fill materials were placed in August 2015, July: Values taken in July 2018, December: Values taken in December 2018.

Accordingly, at the end of three and a half years after the test areas were placed, the systems became more alkaline; there were scarcely any $\mathrm{pH}$ differences between them (Fig. 8). Accordingly, it can be said that systems start to become homogenized and will act on similar values over a long period of time. This finding shows that external effects in the experimental area of the ancient city of Perge are not at a level that will significantly change the $\mathrm{pH}$ level.

\section{Evaluation of Soluble Salt Content Findings}

According to the findings, the soluble salt content values in the samples taken before the fill materials are placed in the test areas and considered as reference values are different from each other. Soil reference value is $2.08 \%$, pozzolana value is $8.03 \%$, sand reference value is $3.12 \%$ and gravel reference value is 
$2.36 \%$. Accordingly, the initial highest soluble salt content value is seen in pozzolana material (Fig. 9). The soluble salt content value in pozzolana is approximately 4 times the soil values, 2.5 times the sand, and about 3.5 times the gravel. However, in July 2018 measurements, it is seen that the values taken from pozzolana have decreased by about half. In December measurements, the values dropped to similar values with all other reburial fills. This suggests that pozzolana was initially at a disadvantage in terms of salinity when it came to using it as a fill material. The decrease in salt values of pozzolana at the end of three and a half years indicates that if this material is to be preferred, it must be used after desalination.

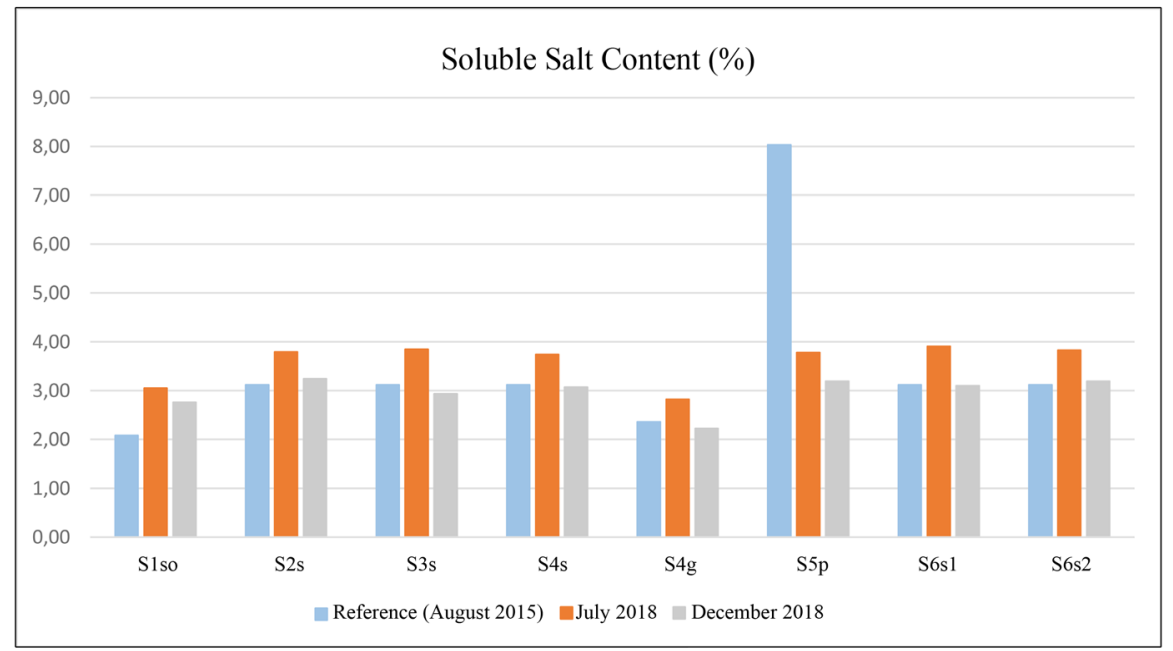

Coding: $\mathbf{S}=$ System (1-6); $\mathbf{A}=$ Test Area (1-18); so: soil, s: sand, g: gravel, p: pozzolana . Reference: Values taken before fill materials were placed in August 2015, July: Values taken in July 2018, December: Values taken in December 2018.

The increase in the total salinity in almost all the test areas in July is related to the concentration of salt on the geotextile and tessera surfaces formed after the rainy period. A decrease in total salinity in all test areas during the humid season in December indicates that salts dissolved by wetting then move into the mosaic pavement.

\section{Evaluation of X-Ray Fluorescence (PED-XRF) Analysis Findings}

According to the PED-XRF analysis findings, sodium salts, which are known to penetrate the environment mostly with the effect of seawater (Cronyn 1990: 22), were detected in low rates in sand and gravel fill materials, including excavated soil other than pozzolana (Fig. 10a). Compared to the reference values obtained in December 2015, the sodium ratio did not show a significant change in the measurements made in the dry period in July 2018 at the end of three years (Fig. 10b) and, following that, in the measurements made in the humid season in December (Fig. 10c). The reason why the sodium content in the pozzolana fill is quite high is due to the volcanic mineral/rocks (such as andesite) in its content. While there was a slight decrease in the rate of sodium salt in the pozzolana fill in Perge monitoring station in July 2018, a significant decrease was observed in December 2018.

Phosphate salts increase due to plant development and animal waste (Cronyn 1990: 22). The highest phosphate ratio in reference samples was found in pozzolana samples (Fig. 10a). The phosphate ratio detected in the pozzolana fill is approximately 1.5 times that of soil and about 8.5 times that of sand. Again, the rate of phosphate in the soil is approximately 5.5 times that of sand. The amount of phosphate salt in gravel samples is slightly lower than sand samples, but it is close.
Figure 9

Total Salt (\%) Analysis Findings of Fill Samples Taken from Test Areas. 
Salt Findings Obtained According to PED-XRF Analysis

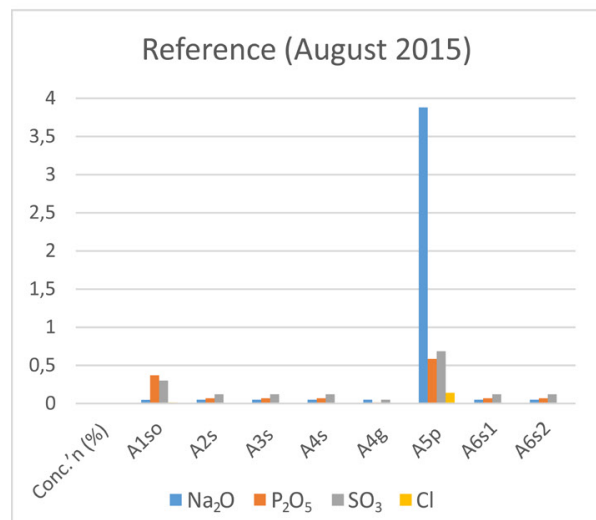

Figure 10

Salt Findings Obtained According to PEDXRF Analysis.

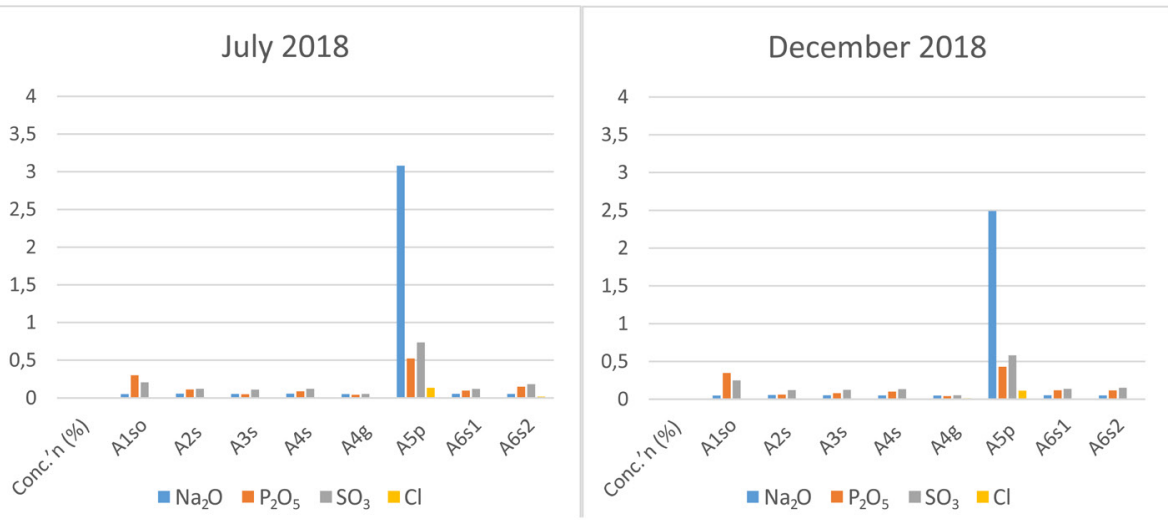

Coding: $\mathbf{S}=$ System (1-6); $\mathbf{A}=$ Test Area (1-18); so: soil, s: sand, $\mathbf{g}$ : gravel, p: pozzolana . Reference: Values taken before fill materials were placed in August 2015, July: Values taken in July 2018, December: Values taken in December 2018.

Accordingly, the gravel and stream sand samples from the fill materials used in the reburial systems in Perge monitoring station provide more positive results in terms of containing less phosphate salt before the fill is placed on the mosaic. When the July 2018 and December 2018 values, which are the dry season of the phosphate salt, were examined mutually, a decrease was observed in the soil compared to the reference value in July 2018 (Fig. 10b). This suggests that some salt found in the excavated soil had dissolved and transferred to the mosaic pavement. On the other hand, some increase in December (Fig. 10c) may be related to the fact that the test area (S1) representing the soil system has higher values in terms of vegetation degree, diversity, and plant growth than other reburial systems. In addition, the dissolution of phosphate salts, which may have been carried due to animals' waste matter transiting to the experimental area in the humid season, may have increased this effect. The decrease in pozzolana fill material compared to the reference values both in July and in December must be related to the fact that the reburial system (S5) made with geotextile and pozzolana, in contrast to the soil fill, showed low values in terms of vegetation degree, diversity, and development. The reference phosphate value of sand fill material is $0.069 \%$. In the July measurement, this ratio decreased slightly to $0.048 \%$ in the A3s sample, which represents the reburial system (S3) formed by geotextile and sand from the tessellatum layer to the surface. Beside this, an increase was observed in all systems using sand. The increase is about 1.5 times the phosphate ratio in the reference material in the A2s sample, which represents the (S2) system created only by sand; about 2 times in the sample (A6s2) taken from the sand layer on the geotextile (A6s2) of the S6 system formed by sand, geotextile, and sand from the tessellatum to the surface. This ratio is lower in samples taken from A4s, representing the reburial system S4, which is formed by geotextile, sand, and gravel from the tessellatum to the surface and sand layer of A6s under geotextile representing the S6 system.

The source of sulphate salts may be the ground waters reaching the surface with the moisture rising from the reservoir in the ground as well as atmospheric pollution (Cronyn 1990: 22). As mentioned above, the soil fill material is sifted excavated soil. The reference sulfate value in the soil fill material is $0.301 \%$ (Fig. $10 \mathrm{a})$. This rate decreased by about 1.5 percent in the A1so July sample $(0.205 \%)$ (Fig.10b). It increased slightly to 0.250 in December but remained below the reference value (Fig. 10c). While the reference sulphate value for pozzolana was 
$0.686 \%$, the A5p sample increased a little $(0.736 \%)$ in July, and this increase must be related to its condensation reaching the fill material, with the moisture rising in the dry season. Following this, the rate fell below the reference value of $0.582 \%$ in December. There are no significant changes in the sulfate values of sand samples in samples other than A6s2. This indicates that very little or almost no sulfate salt is carried to reburial systems.

The A6s 2 samples, representing the $\mathrm{S} 6$ system formed by $5 \mathrm{~cm}$ thick sand, then geotextile and again $20 \mathrm{~cm}$ sand on the mosaic pavement, were obtained from the sand layer under the A6s1 geotextile, just above the tessellatum, and the A6s2 sample was taken just above the geotextile layer. The reference phosphate value of sand, which is $0.069 \%$, increased by about $1.2 \%$ in July in the A6s 1 sample, while A6s2 reached approximately twice the reference value. While the rate in A6s1 increased, it decreased in A6s 2 in the humid season, which is December 2018. The same can be observed in the sample of sulfate salt. The sand reference sulfate value $(0.122 \%)$ remained approximately the same $(0.120 \%)$ in A6s1, while it increased in A6s2 (0.182\%). While A2s1 phosphate and sulphate values increased in December, a decrease was observed in all three salts in A6s2 samples. This indicates that with the moisture rising by capillarity, the salts were carried on the geotextile layer and condensed there, and in the humid season, which is December, it dissolved and moved towards the tessellatum layer again.

The main source of chloride salts is seawater spray. In addition, ground waters also carry a certain amount of chloride (Cronyn 1990: 22). While chloride was $0.015 \%$ in the soil reference sample (Fig. 10a), it decreased to $0.006 \%$ in the M1so sample (Fig. 10b) in July, and this rate did not change in December (Fig. $10 \mathrm{c})$. The rate of chloride salt, which was $0.141 \%$ in the pozzolana reference sample, decreased in M5p samples in July $(0.135 \%)$ and December $(0.112 \%)$. Chloride salt showed no significant change in sand samples other than P6s2. This indicates that the chloride salt flow is extremely low in the reburial systems.

\section{Conclusions and Recommendations}

This research, conducted in Perge, is one of the rare studies conducted on reburial studies of mosaics and the results of which can be evaluated. Soil moisture content and temperature sensors previously used in soil agriculture development research have previously been tried in testing deep burial systems. However, they were used for the first time in this study in shallow-depth burial systems, which are generally preferred for reburial of the mosaics in outdoor conditions and precise and consistent findings were obtained. Climatic measurements obtained from the monitoring station and data taken from the reburial systems coincide with archaeometric data.

Research results have shown that each reburial system has certain advantages and disadvantages. The S1 reburial system, created with the soil fill, provided a certain advantage in terms of not showing a sudden reaction to temperature changes, but had a negative result in terms of all other parameters tested. It seems to be disadvantageous, especially in terms of staying at a constant high moisture content level, having higher values than other reburial systems in terms of vegetation degree, diversity, and plant growth, and possibly in connection with this, especially in terms of the increase in phosphate salts. In these aspects, it is not considered suitable for use in Perge compared to all other reburial systems.

From the initial data, obtained from the monitoring station in 2017, it is the S2 system (created only with sand fill) that showed the highest moisture content values, which was followed by the S1 burial system (created only with soil 
fill). In 2018, there was a significant decrease in the moisture rate in the S2 system and it reached approximate values, and instead it was the S3 system created with geotextile and sand that provided the lowest moisture rate. In these systems, where the fill material is sand in both, it was observed that geotextile provided a significant advantage in moisture transfer in 2017, while the values were almost equal in 2018, which indicates that the effectiveness of geotextile in systems using sand as fill material should be investigated in a long-term and comprehensive manner. Although the sand used in these systems is advantageous in terms of salinity values, it has a disadvantage in terms of allowing plant roots to directly reach the mosaic pavement.

The fact that the moisture rate in the S4 system, which has a sand and gravel layer on the geotextile laid directly on the tessellatum, is higher than in the S2 and S3 systems can be explained by the fact that due to the large porous structure of the upper gravel layer, it breaks the capillarity that allows the moisture in the system to evaporate. This system also exhibits negativity in terms of its sudden response to precipitation.

The S5 reburial system, which was created with geotextile and pozzolana on the tessellatum layer, provides positive results in terms of not showing a sudden reaction to precipitation, and maintaining the temperature balance, as well as remaining at low moisture content levels. However, it contains a high amount of salt depending on the raw material source it comes from. If it is preferred to use the pozzolana due to its advantages, then it must be subjected to a desalination process, as the pozzolana contains more sodium, sulphate, phosphate, and chloride salt than all other fill materials.

The S6 system, where a thin layer of sand is first applied to the tessellatum layer and geotextile and sand fill is applied on it again is the most advantageous system in terms of slowing the plant roots to reach the mosaic. However, it showed a performance that can be called negative in terms of almost every other parameter in question.

Soil, sand, pozzolana, and gravel materials show the characteristics of raw material sources in terms of total salinity. According to the findings of total salt analysis, $\mathrm{pH}$ analysis and PED-XRF analysis, a decrease was usually observed following a relatively long period of 3 years after the placement of the test areas in all fill materials, except soil fill in the reburial systems. Accordingly, it is understood that the salt and $\mathrm{pH}$ in the environment depend on the source from which the material comes, rather than on external factors in the experimental area. Reducing the salt and $\mathrm{pH}$ rates in the reburial environment indicates that the material supplied for use as a fill layer must be tested according to these criteria when selected.

The flowering periods of the plants detected in Perge monitoring station are based on the variety, lasting from February to December. Changing the $2 \mathrm{~cm}$ part of the soil after the majority of plants have shed their seeds, for example in October, can be beneficial for preventing the plants from growing again. Total effective herbicides with systemic effect entering from tissues in contact with the plant and moving from here to other plant organs can be used for biennial, perennial, bi- or perennial, mono or biennial species, as well as single annual plants. Given the variety of flowering and life expectancy of plants detected in the monitoring station, it is recommended that disinfection processes be performed at least three times a year. In addition, the removal of species such as caper (capparis ovata sp.) and dog's tooth grass (cynodon dactylon) in the protection area from overgrowth with regular maintenance will be the most appropriate solution in terms of protection. 
Acknowledgement

Field tests were carried out in the ancient city of Perge under the supervision of the Antalya Archeology Museum with the permission of the Ministry of Culture and Tourism, Directorate General for Cultural Heritage and Museums. The thesis was financially supported by the Istanbul University Scientific Research Fund (Project coded SDK-2016-3775) and Işık University Scientific Research Fund (Project coded 15B701). The author expresses her gratitude to her thesis advisor Assoc. Prof. Dr. H. Iş1l ÖZSAİT-KOCABAŞ for her support in this research carried out within the scope of the doctoral thesis, to Prof. Dr. Melih BOYDAK who provided full support throughout the whole research as well as his guidance in vegetation studies, to Assoc. Prof. Dr. Ali KAVGACI who conducted the analysis on the species-genus/taxa and degree of coverage of plants and to Assoc. Prof. Dr. Ali Akın AKYOL for his support in conducting archaeometric analysis.

\section{Bibliography - Kaynaklar}

Agnew et al. 2004

Aksoy 1978

Bakış et al. 2011

Boydak - Çalışkan 2014

Braun-Blanquet 1928

Braun-Blanket 1932

Braun-Blanquet 1964

Burch - Agnew 2004

Caneva et al. 1991

Caple 2004

Cronyn 1990

Davis 1965-1985

Davis et al. 1988

Demas 2004

Demas 2012

Erdek 2012

Erdek 2019

Güner et al. 2000

Işıklıkaya 2010
N. Agnew - J. Barrow - M. Demas - D. Ford - H. Roby - N. Stanley-Price - M. R. Taylor - J. M. Teutonico, "Reburial of archaeological sites: A colloquium organized by the Getty Conservation Institute, the National Park Service (Intermountain Region) and ICCROM Santa Fe, New Mexico, 17-21 March 2003”, CMAS 6, 3-4, 133-135.

H. Aksoy, Karabük, Büyükdüz Araştırma Ormanındaki Orman Toplumları ve Bunların Silvikültürel Özellikleri Üzerine Araştırmalar, No 2332, İstanbul.

Y. Bakıș - M. T. Baba - E. Uslu, "Updates and Improvements of Turkish Plants Data Service (TÜBİVES)”, J. Allmer (ed.), $6^{\text {th }}$ International Symposium on Health Informatics and Bioinformatics (HIBIT), İzmir, 136-140.

M. Boydak - S. Çalışkan, Ağaçlandırma, CTA, Ankara.

J. Braun-Blanquet, Pflanzensoziologie: Grundzüge der Vegetationskunde, Biologische Studienbücher 7, Berlin.

J. Braun-Blanquet, Plant Sociology. The study of plant communities, New York and London.

J. Braun-Blanquet, Pflanzensoziologie: Grundzüge der Vegetationskunde 3b, Wien-New York.

R. Burch - N. Agnew, "Reburial research: A conceptual design for field testing for the reburial of wall plasters and mosaic pavements", CMAS 6, 3-4, 347-361.

G. Caneva - M. P. Nugari - O. Salvadori, Biology in the Conservation of Works of Art, ICCROM, Rome.

C. Caple, "Towards a benign reburial context: the chemistry of the burial environment", CMAS 6, 155-165.

J. M. Cronyn, The Elements of Archaeological Conservation, London.

P. H. Davis, Flora of Turkey and the East Aegean Islands, Vol. I-IX, Edinburgh.

P. H. Davis - R.R. Mill - K. Tan, Flora of Turkey and the East Aegean Islands, Vol. X, Edinburgh.

M. Demas, "Site unseen': the case for reburial of archaeological sites”, CMAS 6, 137-154.

M. Demas, "Reburial and Protective Covering of Mosaics", T. Roby - M. Demas (eds.), Mosaics In Situ: An Overview of Literature on Conservation of Mosaics In Situ, Los Angeles, 1-17 (Online). https://www.getty.edu/ conservation/publications_resources/pdf_publications/pdf/lit_review.pdf (27 June 2021).

Ş. Erdek, Perge Mozaiklerinin Korunması, Sergilenmesi ve Bakımı: Yöntem Önerileri, Yayımlanmamış Yüksek Lisans Tezi, İstanbul Üniversitesi, Sosyal Bilimler Enstitüsü, İstanbul.

Ş. Erdek, In situ Mozaik Taban Döşemelerinin Korunmasında Tekrar Gömme Sistemlerinin Değerlendirilmesi ve Öneriler, Yayımlanmamış Doktora Tezi, İstanbul Üniversitesi, Sosyal Bilimler Enstitüsü, İstanbul.

A. Güner - N. Özhatay - T. Ekim - K. H. C. Başer, Flora of Turkey and the East Aegean Islands, Vol. XI, Edinburgh.

I. R. Işıklıkaya, Perge Mozaikleri: Macellum, Güney Hamam ve Geç Antik Dönem Meydanı Doğu Portiği, Yayımlanmamış Doktora Tezi, İstanbul Üniversitesi, Sosyal Bilimler Enstitüsü, İstanbul. 
Iș1klıkaya-Laubscher 2016

Kavgac1 2007

Özdizbay 2012

Roby 2004

Stewart 2004

Uğur 2011

Yeşil-Erdek 2014
I. R. Işıklıkaya-Laubscher, "Perge Mozaik Atölyeleri ve Akdeniz Havzası Mozaik Ekolleri İçerisindeki Yeri”, Adalya XIX, 169-227.

A. Kavgacı, Demirköy-İğneada Longoz Ormanları ve Çevresinin Bitki Toplumları ve Kuruluş Özellikleri, Yayımlanmamış Doktora Tezi, İstanbul Üniversitesi, Fen Bilimleri Enstitüsü, İstanbul.

A. Özdizbay, Perge'nin M.S. 1.-2. Yüzyıllardaki Gelişimi, Adalya Ekyayın Dizisi 10, Antalya.

T. Roby, "The reburial of mosaics: an overview of materials and practice", CMAS 6, 3-4, 229-236.

J. Stewart, "Conservation of Archaeological Mosaic Pavements by Means of Reburial", CMAS 6, 3-4, 237-246.

T. Uğur, Perge Antik Kentine Ait Mozaik Harçlarının Karakterizasyonu, Yayımlanmamış Yüksek Lisans Tezi, İstanbul Üniversitesi, Sosyal Bilimler Enstitüsü, İstanbul.

Ş. Yeşil-Erdek, "Perinthos-Herakleia Bazilikası Taban Döşemelerinin Konservasyonu”, JMR 7, 61-76. 
